\title{
DIREITOS FUNDAMENTAIS, DEVER ESTATAL DE SEGURANÇA PÚBLICA E CIDADANIA: O CONTROLE SOCIAL DAS POLÍTICAS PÚBLICAS NA GARANTIA DO EXERCÍCIO PROPORCIONAL DO PODER DE POLÍCIA
}

\author{
FUNDAMENTAL RIGHTS, STATE DUTY OF PUBLIC SAFETY AND CITIZENSHIP: THE \\ SOCIAL CONTROL OF PUBLIC POLICIES IN THE GUARANTEE OF THE PROPORTIONAL \\ EXERCISE OF POLICE POWER
}

Emerson Affonso da Costa Moura

Professor Adjunto da Universidade Federal Rural do Rio de Janeiro (UFRRJ) Doutor em Direito pela Universidade do Estado do Rio de Janeiro (UERJ) Mestre em Direito Constitucional e Especialista em Direito Administrativo da Universidade Federal Fluminense (UFF) Email: emersonacmoura@yahoo.com.br

Recebido em: 17/08/2018 Aprovado em: 01/03/2019

\begin{abstract}
RESUMO: O controle social das políticas públicas de segurança pública como instrumento que permite auxiliar na verificação do cumprimento do dever estatal de promoção dos direitos fundamentais além de fortalecer os mecanismos de cidadania no que tange a repressão da violência é o tema posto em debate. Analisa-se o papel de centralidade assumido pelos direitos fundamentais no Estado Democrático de Direito que impõe obrigações aos poderes públicos e, em específico, deveres de concretização pelo Estado-Administração através da realização de políticas públicas. Após, aborda-se o direito fundamental à segurança e as políticas públicas normativas e administrativas de garantia da incolumidade aos bens e pessoas, verificando a necessidade de exercício proporcional do poder de polícia e o importante papel do controle social no que tange à garantia de fiscalização das medidas contra a violência e do exercício da cidadania em matéria de segurança pública. Para tanto, utiliza-se por metodologia a crítica dialética com primazia de uso de fonte bibliográfica através do apoio na doutrina pátria e estrangeira através dos principais expoentes na matéria.
\end{abstract}

Palavras-Chaves: Direitos Fundamentais; Direito a Segurança; Segurança Pública; Políticas Públicas; Controle Social.

ABSTRACT: The social control of the public policies of public security as an instrument that
helps to verify the fulfillment of the state duty to promote fundamental rights, besides strengthening
the mechanisms of citizenship regarding the repression of violence, is the subject under discussion.
The role of centrality assumed by fundamental rights in the Democratic State of Law, which
imposes obligations on the public authorities and, in particular, on the implementation of public
policies by the State Administration is analyzed. After that, the fundamental right to security and
the normative and administrative public policies of guarantee of the security to the goods and
people are verified, verifying the necessity of proportional exercise of police power and the
important role of the social control with regard to the guarantee of inspection measures against
violence and the exercise of citizenship in matters of public security. For that, is used dialectical 
criticism methodology with primacy of bibliographic font through the support of homeland and foreign doctrine through the main exponents in the matter.

Keywords: Fundamental Rights; Right to Security; Public security; Public policy; Social Control.

SUMÁRIO: Introdução; 1 Os Direitos Fundamentais no Estado Democrático de Direito; 2 O dever de concretização dos Direitos Fundamentais pelo Estado-Administração; 3 Direito à Segurança e Políticas Públicas; 4 Segurança Pública e Poder de Polícia; 5 As Políticas Públicas de Segurança e o Controle Social; Conclusão; Referências.

\section{INTRODUÇÃO}

O tema segurança pública pode ser visto à partir da sua interface entre direito e política entre as normas programáticas determinadas pelas Constituição Republicana e as políticas públicas realizadas pelos governos, na dialética permanente entre as escolhas políticas fundamentais e as vontades majoritárias atuais.

Neste viés, embora as autoridades tenham um livre espaço de discricionariedade para determinar as políticas públicas que irão concretizar a segurança pública, sob o vértice jurídico a consagração dos direitos fundamentais do cidadão impõe aos poderes públicos o dever de sua concretização mediante ações adequadas à garantia da segurança e proteção da paz social.

Problematiza a questão à luz dos conflitos de desigualdade, da explosão de violência e a crescente criminalidade que ocorrem nos espaços urbanos e a atuação repressiva estatal através de políticas públicas de segurança e a sua (não) inserção em um espaço de construção de cidadania ativa.

Neste viés, o controle pela sociedade pode corresponder a instrumento importante para a recondução das políticas públicas de segurança pública à efetiva proteção dos direitos sociais como forma de garantir o exercício da cidadania no que se refere as medidas de contenção da violência e promoção da paz social.

Busca o presente trabalho analisar em que medida o controle social das políticas públicas de segurança pública é instrumento que permite auxiliar na verificação do cumprimento do dever estatal de promoção dos direitos fundamentais além de fortalecer os mecanismos de cidadania no que tange a repressão da violência.

Para tanto, analisa-se o papel de centralidade assumido pelos direitos fundamentais no Estado Democrático de Direito que impõe obrigações aos poderes públicos e, em específico, deveres de concretização pelo Estado-Administração através da realização de políticas públicas e oferecimento dos serviços públicos e a regulação adequada.

Após, aborda-se o direito fundamental à segurança e as políticas públicas normativas e administrativas de garantia da incolumidade aos bens e pessoas, verificando a necessidade de exercício proporcional do poder de polícia e o importante papel do controle social no que tange à garantia de fiscalização das medidas contra a violência e do exercício da cidadania.

Para tanto, utiliza-se por metodologia a crítica dialética com primazia do uso de fonte bibliográfica através do apoio na doutrina pátria e estrangeira através dos principais expoentes na matéria, bem como, da utilização da legislação e jurisprudência quando considerada pertinente. 


\section{OS DIREITOS FUNDAMENTAIS NO ESTADO DEMOCRÁTICO DE DIREITO}

Embora os direitos fundamentais, tenham antecedentes histórico na doutrina estóica greco-romana e cristã da Antiguidade ${ }^{1}$ e desenvolvimento nas doutrinas jusnaturalistas ${ }^{2}$ e previsão de direitos estamentais na Idade Média $^{3}$ a sua consagração ocorre apenas com o constitucionalismo na Idade Moderna, pelo reconhecimento nas principais Cartas e Constituições ${ }^{4}$.

No Estado Moderno, a evolução dos direitos fundamentais se liga ao processo histórico de reinvindicações sociais e contrastes de regimes políticos, bem como, o processo de desenvolvimento econômico, científico e político, que resulta em um primeiro momento na tensão dialética e harmonização entre liberdade e igualdade, direitos individuais e direitos sociais ${ }^{5}$.

Inicialmente, abrangiam os direitos individuais em razão do pensamento liberal-burguês e da doutrina iluminista e jusnaturalista do século XVII e XVIII, que se identificavam com os direitos negativos e marcavam a esfera de autonomia do indivíduo em face do poder estatal no exercício precípuo das liberdades. ${ }^{6}$

Porém, com a ascensão dos problemas sociais e econômicos no limiar do século XIX, os direitos fundamentais foram ampliados para incluir os direitos econômicos, sociais e culturais, que

${ }^{1}$ Os valores da dignidade da pessoa humana, da liberdade e da igualdade dos homens encontra suas raízes na filosofia
clássica, em especial, na greco-romana e no pensamento cristão. Embora na antiguidade greco-romana inexistisse
direitos do homem válidos para todos, com os sofistas e, em especial, os estoicos romanos, adveio as teses da igualdade
de todos os homens em dignidade como lei natural. No cristianismo, a partir dos ensinamentos do homem e sua
semelhança à imagem de Deus, adveio a tese da unidade de humanidade, dignidade e liberdade de todas as pessoas.
CARVELI, Urbano. SCHOOL, Sandra. Evolução Histórica dos Direitos Fundamentais: Da Antiguidade até as
Primeiras Importantes Declarações Nacionais de Direito. Revista de Informação Legislativa, Brasília, a. 48 n. 191 p. 169-171 jul/set 2011.

${ }^{2} \mathrm{~A}$ unidade universal dos homens e a igualdade cristã de todos foram as premissas para o desenvolvimento no jus naturalismo medieval, da idéia de postulados supra positivos que orientavam e limitavam, atuando como critério de legitimidade, o exercício do poder, de tal sorte que o direito natural condicionará à sua conformidade a obediência do direito positivo. Com as teorias contratualistas as doutrinas jusnaturalistas de direitos fundamentais encontram sua evolução, abrindo espaço para o reconhecimento normativos de tais direitos. LUÑO, Antonio Enrique Perez. Los Derechos Fundamentales. Madrid: Tecnos, 2004. p. 29-33.

${ }^{3}$ Embora sempre citada a Magna Charta Libertatum, firmada em 1215 pelo Reuo João Sem-terra e pelos bispos e barões ingleses, que consagra direitos e liberdades clássicos, como o habeas corpus, o devido processo legal e a garantia da propriedade, as cartas de franquia e os forais outorgados pelos reis e portugueses e espanhóis no século XII e XIII, bem como, a Bula de Ouro da Hungria firmada por Afonso IX em 111, o Privilegio General outorgado por Pedro III em 1283 e os Privilégios da União Aragonesa em 1286 já veiculavam prerrogativas ou privilégios aos estamentos sociais (Nobreza, Igreja, Corporações), que não correspondiam a direitos fundamentais, mas obrigações concretas daqueles reis que o subscreviam. ANDRADE, José Carlos Vieira de. Direitos Fundamentais na Constituição de 1976. Coimbra: Almedina, 2001. p. 25

${ }^{4}$ Com as declarações inglesas de direito - Petition Of Rights de 1628, Habeas Corpus Act de 1679, Bill Of Rights de 1689 - foram reconhecido direitos e liberdades aos cidadãos ingleses, como a legalidade, a proibição de prisões arbitrárias e o habeas corpus, que significa a transposição das liberdades estamentais para as liberdades gerais no plano de direito público. Com a Declaração americana de Direitos do Povo da Virgínia de 1776 e a Declaração francesa dos Direitos do Homem e do Cidadão de 1789 se marca a transição dos direitos de liberdade legais ingleses para os direitos fundamentais constitucionais. SARLET, Ingo Wolfgang. Op. cit. p. 42-43.

${ }^{5}$ A evolução e as vicissitudes dos direitos fundamentais, seja numa linha de alargamento e aprofundamento, seja numa linha de obnubilação, acompanham o processo histórico, as lutas sociais e os contrastes de regimes políticos, m bem como, o progresso científico, técnico e econômico. Do Estado liberal ao Estado social de Direito, o desenvolvimento dos direitos fundamentais faz-se no interior das instituições representativas de maneira bastante variada, buscando harmonizar os direitos de liberdade e direitos econômicos, sociais e culturais. MIRANDA, Jorge. Os Direitos Fundamentais... Op. cit. p. 199.

${ }^{6}$ Embora sob a influência da doutrina de Hobbes, Locke, Rousseau e Kant que proclamam a liberdade do indivíduo, proclamavam as cartas os direitos não de todos os homens, uma vez que a maior parte dessas Constituições estabeleciam o sufrágio censitário, mas do homem burguês, com a tutela da propriedade privada de forma sagrada e inviolável, razão pelo qual os textos eram considerados como patrimônio do indivíduo em sua condição presencial. LUÑO, Antonio Enrique Perez. Op. cit. p. 38.

Revista de Direito Brasileira | Florianópolis, SC | v. 22 | n. 9 | p. 4-28 |Jan./Abr. 2019 
se correlacionando com os direitos positivos, passaram a impor ao Estado atuações capazes de promover a justiça e bem-estar social, na tutela do princípio da igualdade ${ }^{78}$.

Não obstante, naquela quadra histórica, já houvesse o reconhecimento pelos Estados dos direitos fundamentais em sua dúplice dimensão, a concepção da Constituição como documento político que podia não ser cumprido pelos poderes públicos ${ }^{9}$ e a aceitação apenas da dimensão subjetiva dos direitos fundamentais, limitava a sua eficácia pelo Estado e particulares ${ }^{1011}$.

Porém, observa-se com o término da segunda guerra mundial na Europa e o advento do processo de redemocratização do Brasil, uma série de transformações na forma de organização política e jurídica estatal, que marcam o advento do Estado Democrático de Direito e a ascensão dos pilares fundamentais do constitucionalismo contemporâneo ${ }^{12}$.

Com o reconhecimento da força normativa da Constituição ${ }^{13}$, substitui-se a concepção da lei fundamental como carta política com a atribuição do status de norma jurídica, que dotada de observação obrigatória, impõe no exercício do poder pelo Estado, limites e deveres de atuação, em especial, na tutela dos direitos fundamentais. ${ }^{14}$

Com o processo de incorporação de amplo elenco de direitos fundamentais aos textos constitucionais, bem como, a expansão da jurisdição constitucional, mediante a ampliação do

\footnotetext{
${ }^{7}$ Quando o Estado coagido pela pressão das massas ao poder político, confere os direitos do trabalho, da previdência, da educação e outros, coloca a sociedade dependente de sua intervenção no domínio econômico, político e social, em restrição da iniciativa individual aos interesses sociais, demonstra a passagem de um Estado Liberal para um Estado Social. BONAVIDES, Paulo. Do Estado Liberal ao Estado Social. 8 ed. São Paulo: Malheiros, 2007. p. 186.

${ }^{8}$ Embora tanto na concepção liberal quanto social se deparam liberdade e igualdade, na primeira a igualdade é a titularidade dos direitos que demanda liberdade para todos, ao passo que, na segunda a igualdade é a concreta igualdade de agir e a liberdade a própria igualdade puxada para ação. MIRANDA, Jorge. Direitos... Op. cit. p. 199-200.

${ }^{9}$ Um dos trabalhos expoentes deste entendimento é Que é uma Constituição? de Ferdinand Lassalle, que considera que a Constituição só tem eficácia quando coincidir com os fatores do poder que regem o país. Caso contrário é apenas folha de papel que pode sucumbir por aquelas forças vitais que não iram aplicá-la. LASSALLE, Ferdinand. Que é uma Constituição. São Paulo: Edições e Publicações Brasil, 1933. P. 62

${ }^{10}$ Embora a expressão Estado de Direito importe no limite do exercício do poder político e direitos fundamentais deva estar ligada à proteção e promoção dos direitos fundamentais da pessoa humana, a expressão já foi reconhecida por entes estatais apenas para a proclamação formal de direitos ou assegurar a proteção jurídica para os privilégios de minorias mais favorecidas. É necessário compatibilizar o Estado de Direito com direitos fundamentais, como instrumentos de garantia da democracia e proteção do homem e sua dignidade. DALLARI, Dalmo de Abreu. Estado de Direito e Direitos Fundamentais in: AMLEIDA FILHO, Agassiz de. CRUZ, Danielle da Rocha (Coord). Estado de direito e direitos fundamentais: homenagem ao jurista Mário Moacyr Porto. Rio de Janeiro: Forense, 2005. p. 171.

${ }^{11}$ Embora acolhidos e protegidos pela Constituição, os direitos fundamentais conquistados pela sociedade sempre estiveram sob contínuo descumprimento pelo Estado, inclusive, hoje na atualidade sob o escopo de doutrinas jurídicas que buscam justificar se descumprimento, em razão de contingência de recursos e outros fundamentos. TAVARES, Marco Aurélio Romagnloi. Ativismo judicial e políticas públicas: direitos fundamentais. Porto Alegre: Sergio Antonio Fabris, 2011 p. 101-103.

${ }^{12}$ Como marco normativo, tem-se a promulgação da Lei Fundamental de Bonn na Alemanha e a Constituição da Itália, e a posterior, das cartas fundamentais de Portugal e Espanha. Alcança o fenômeno para além do velho continente, encontrando no Brasil com o fim da ditadura militar e a edição da Constituição da República, o ambiente propício para a garantia da estabilidade institucional e da aplicabilidade das normas constitucionais. Sobre o tema: CARBONELL, Miguel. Nuevos Tiempos para el Constitucionalismo in: CARBONELL, Miguel (Org). Neoconstitucionalismo(s). 1 ed. Madrid: Editorial Trotta, 2003. p. 9.

${ }^{13}$ Uma das obras percussoras sobre o tema é A força normativa da Constituição de Konrad Hesse extraída a partir de sua aula inaugural na cátedra da Universidade de Freiburg. Segundo o autor, a norma constitucional não tem existência autônoma em face da realidade, mas tão pouco se limita ao reflexo das condições fáticas. Sua essência reside na pretensão de eficácia, ou seja, de sua concretização na realidade imprimindo-lhe ordem e conformação. HESSE, Konrad. A força normativa da Constituição. Porto Alegre: Sergio Antonio Fabris Ed., 1991. p. 14-15.

${ }^{14}$ Sobre as transformações do direito constitucional contemporâneo, consulte-se por todos: BARROSO, Luís Roberto. Neoconstitucionalismo e constitucionalização do direito: O triunfo tardio do direito constitucional no Brasil. In: SOUZA NETO, Cláudio Pereira de; SARMENTO, Daniel (orgs.). A constitucionalização do direito: fundamentos teóricos e aplicações específicas. Rio de Janeiro: Lumen Juris, 2007. p. 203-250. Para uma análise crítica vide: SARMENTO, Daniel. O neoconstitucionalismo no Brasil: Riscos e possibilidades. In: constitucional contemporânea. Rio de Janeiro: Lumen Juris, 2009. p. 113-146.

(org.). Filosofia e teoria
}

Revista de Direito Brasileira | Florianópolis, SC | v. 22 | n. 9 | p.4-28 |Jan./Abr. 2019 
elenco de legitimados para a propositura das ações e a criação de novos instrumentos de controle concentrado, garante-se a proteção dos direitos fundamentais do processo político majoritário ${ }^{15}$.

Na nossa experiência constitucional antes restrita a Constituições garantista que tutelavam os direitos fundamentais como repositórios de promessas vagas ${ }^{16}$ o fenômeno ocorre com a promulgação da Constituição de 1988 voltada à promoção social e a crescente preocupação doutrinária com a aplicabilidade direta e imediata de seus preceitos ${ }^{17}$.

Com a constituição cidadã se ampliou o rol de direitos fundamentais, atribuindo significado ímpar aos mesmos, uma vez que os reconheceu como elementos integrantes de identidade e continuidade da lei fundamental, razão pelo qual, vedou qualquer reforma constitucional tendente a suprimi- $\operatorname{los}^{18}$.

Interrompeu-se, portanto, o ciclo inicial de baixa normatividade das disposições que veiculavam os direitos fundamentais, em especial, das normas que declaravam os direitos sociais, antes remetidas à esfera programática de meras linhas diretoras aos poderes públicos e, tidas como dotadas de eficácia limitada. ${ }^{19}$

Por outro lado, houve também, o reconhecimento além de uma dimensão subjetiva dos direitos fundamentais - de proteção de situações individuais em face do poder público e dos particulares - de uma objetiva - de consagração de uma ordem objetiva de valores essenciais a sociedade $^{20}$, que projetam a unidade da Constituição e a congruência dos seus preceitos ${ }^{21}$.

Por efeito, os direitos fundamentais enquanto objetivamente considerados passaram a impor normas de competência negativa, retirando da esfera de ação exclusiva dos poderes públicos, funcionam como critério de interpretação do direito infraconstitucional, que devem se adequar as suas prescrições, bem como, impõe deveres de tutela ao ente estatal ${ }^{22}$.

\footnotetext{
${ }^{15}$ Insere-se, portanto, o exercício da jurisdição constitucional orgânica e das liberdades no complexo de mecanismos de natureza normativa, institucional ou processual tendentes a assegurar a plena realização dos direitos fundamentais. COELHO, Rosa Júlia Plá. Mecanismos de Proteção dos Direitos Fundamentais. 1 ed. Brasília: Ordem dos Advogados do Brasil, 2005. p. 34.

${ }^{16}$ Não é incomum a existência formal de Constituições que invocam o que não está presente, afirmam o que não é verdade e prometem o que não será cumprido. Como, e.g., tem-se a Constituição de 1969 que garantia os direitos à integridade física e a vida, com as prisões ilegais, a tortura e o desaparecimento de pessoas na ditadura. BARROSO, Luís Roberto. O direito constitucional e a efetividade de suas normas. Limites e possibilidades da Constituição brasileira. 7. ed. Rio de Janeiro: Renovar, 2003. p. 61.

${ }^{17}$ Embora a Constituição de 1988 seja o resultado de forças políticas antagônicas que participaram da constituinte, materializando uma constante tensão entre a ideologia liberal e a perspectiva social, denota-se um grande avanço na disciplina dos direitos sociais em relação às Constituições anteriores. Para uma visão geral sobre a evolução histórica, vide: TORRES, Marcelo Nóbrega da Câmara. Direitos sociais. Brasília: Senado Federal, 1987.

${ }^{18}$ A própria colocação do catálogo dos direitos fundamentais no início do texto constitucional, bem como, a amplitude do rol do artigo $5^{\circ}$ denota a intenção do constituinte de emprestar significado especial e a posição de destaque concedida aos direitos fundamentais pela Constituição Federal. MENDES, Gilma Ferreira. Op. cit. p. 1.

${ }^{19}$ A aplicabilidade restrita das normas de natureza programática decorreria da fluidez de suas disposições e da inexistência de instrumentos jurídico-processuais capazes de garantir sua concretização.

Compreendendo que as relações econômico-sociais são disciplinadas apenas por normas programáticas, vide: SILVA, José Afonso da. Aplicabilidade das normas constitucionais. 7. ed. São Paulo: Malheiros, 2008. p. 140-142.

${ }^{20}$ Liga-se a dimensão objetiva a compreensão de que os direitos fundamentais consagram os valores mais importantes da comunidade política potencializando a sua irradiação para todos os campos do Direito, e sua eficácia enquanto fins ou valores comunitários sobre uma miríade de relações jurídicas. SARMENTO, Daniel. Direitos Fundamentais e Relações Privadas. Rio de Janeiro: Lumen Juris, 2004. p. 371.

${ }^{21}$ Com a introdução dos direitos fundamentais da segunda geração, passou-se a compreender os critérios objetivos de valores, bem como, os princípios básicos que animam a Constituição, projetando a sua unidade e fazendo a congruência fundamental de suas regras. Esses direitos, passam a representar uma unidade de ordenação valorativa, de garantia contra arbítrios do Estado. BONAVIDES, Paulo. Curso de... Op. cit. p. 569.

${ }^{22}$ A dimensão objetiva, portanto, é aquela cuja percepção independe de seus titulares, ou seja, dos sujeitos de direito, e que oferecem controle de ação estatal, que devem ser aplicados independente de intervenções ou violações de direitos fundamentais, bem como da reclamação por seu titular. Assim, enquanto: caráter de normas de competência negativa, enseja o autocontrole abstrato de constitucionalidade das normas, mediante a legitimidade dada as autoridades estatais; como critério de interpretação do direito infraconstitucional, impõe a interpretação conforme a Constituição pelo

Revista de Direito Brasileira | Florianópolis, SC | v. 22 | n. 9 | p. 4-28 |Jan./Abr. 2019
} 
Com esse novo status adquiridos, os direitos fundamentais passaram a assumir, também, a posição de centralidade no sistema jurídico, instituindo uma ordem objetiva de valores que irradia sua força normativa por todo o ordenamento, condicionando a interpretação das normas e institutos dos ramos do Direito e vinculando a atuação dos poderes públicos ${ }^{23}$.

Também, passam a corresponder ao lado dos princípios estruturais e organizacionais um núcleo básico do ordenamento constitucional ${ }^{24}$ e critério de interpretação de suas normas, categorias e institutos, em um fenômeno de abertura constitucional ou de constitucionalização em aberto, que importa na irradiação ou expansão da dignidade e dos direitos do homem ${ }^{25}$.

O Estado Democrático de Direito passa ser caracterizado por uma abertura constitucional radicado no extenso catálogo de direitos fundamentais - civis, políticos, econômicos, sociais e culturais - que com epicentro no princípio da dignidade da pessoa humana alcança a superação da tradicional divisão de domínio e papéis do Estado e da sociedade civil ${ }^{26}$.

Ademais, transforma-se também, como um dos critérios de verificação da legitimidade do Estado, que passa a ser medido pelo grau de observância e de implementação dos direitos fundamentais radicados da dignidade da pessoa humana pelos poderes públicos de forma direta ou através da atuação de terceiros ${ }^{27}$.

A própria concepção dos direitos fundamentais, passa a determinar o significado dos poderes públicos, uma vez que, há uma íntima relação entre o papel assumido por esses direitos públicos subjetivos e a organização e exercício das funções estatais, uma vez que garantem que o sistema político e jurídico se orientará pelo respeito e promoção da pessoa humana ${ }^{28}$.

Por efeito, o reconhecimento normativo dos direitos fundamentais e o papel assumido pelo seu sistema no Estado Democrático de Direito, reorienta a relação da pessoa com os poderes públicos, redimensionando a atuação administrativa ao respeito e concretização tanto dos preceitos fundamentais, quanto da dignidade da pessoa humana.

aplicador do Direito; Por fim, enquanto dever estatal de tutela, impõe a postura de proteção ativa do Estado nas violações. DIMOULIS, Dimitri. MARTINS, Leonardo. Teoria Geral dos Direitos Fundamentais. São Paulo: Editora Revista dos Tribunais, 2008. p. 118-121.

23 Apresentam os direitos fundamentais, portanto, uma dupla ordem de sentido: como vínculos axiológicos, que condicionam a validade material das normas produzidas e enquanto fins que orientam o Estado Constitucional de Direito. FERRAJOLI, Luigi. Derechos e Garantias: La ley del mais débil. 1 ed. Madrid: Trotta, 1999. p. 22.

${ }^{24}$ Os direitos fundamentais como resultado da personalização e positivação constitucional de determinados valores básicos para integrar a substância propriamente dita da Constituição formado pelas decisões fundamentais da ordem normativa, revelando que mesmo num Estado Democrático de Direito se torna necessária certas vinculações de cunho material para fazer frente aos espectros da ditadura e do totalitarismo. SARLET, Ingo Wolfgang. Op. cit. p. 61.

25 É alçado em forja central da eclética e difusão produção de valores e princípios encarecidos pela sociedade contemporânea. CASTRO, Carlos Roberto Siqueira. p. 20-21.

${ }^{26}$ De certo modo, o postulado da dignidade humana universalizou-se como um polo de atração para cada vez mais novos direitos refletores de um novo modo de atuação do Estado Democrático de Direito. Assim, encontramos o na Constituição do México de 1917 (Art. 3 II “c”), da Itália de 1947 (Art. 3º), da Alemanha de 1949 (Art. $1^{\circ}$ ), de Portugal de 1976 com redação dada pela Lei Constitucional 1 de 1989 (Art. $1^{\circ}$ ). Espanha de 1978 (Art. 47) e na do Brasil de 1988 (art. $1^{\circ}$ III, art. 170, art. 226 \$7º, art. 227 e 230). CASTRO, Carlos Roberto Siqueira. A Constituição Aberta e os Direitos Fundamentais: ensaios sobre o constitucionalismo pós-moderno e comunitário. Rio de Janeiro: Forense, 2010. p. 15-19.

${ }^{27}$ Uma Constituição que consagre um Estado de Direito não pode admitir que qualquer governante ou órgão do Estado possa agir arbitrariamente, fora dos limites constitucionais, sob pretexto de conveniência pública ou de necessidade e urgência que justifique a prática de atos arbitrários. $\mathrm{O}$ verdadeiro Estado de Direito é aquele que assegura a prática da democracia e a proteção da dignidade da pessoa humana. DALLARI, Dalmo de Abreu. Op. cit. p. 182-183.

${ }^{28} \mathrm{O}$ respeito e promoção dos direitos fundamentais tanto em sua dimensão individual que caracteriza o Estado Liberal de Direito, quanto conjugando-o com a exigência de solidariedade corolário do componente social e coletivo da vida humana do Estado Social de Direito. LUÑO, Antonio Enrique Perez. Op. cit. p. 20.

Revista de Direito Brasileira | Florianópolis, SC | v. 22 | n. 9 | p.4-28 |Jan./Abr. 2019 


\section{O DEVER DE CONCRETIZAÇÃO DOS DIREITOS FUNDAMENTAIS PELO ESTADO- ADMINISTRAÇÃO}

Com o advento do Estado Liberal de Direito, a legalidade tornou-se postulado fundamental do Direito Público, vinculando o agir estatal à legislação emanada pelo poder competente segundo as prescrições formais, porém, independente do grau de adequação material a vontade de seus titulares $^{29}$, sendo alçado, portanto, à parâmetro de juridicidade da Administração Pública.

Entretanto, o reconhecimento da normatividade da Constituição com a consolidação de sua supremacia hierárquica e axiológica na ordem jurídica, bem como, o advento da pluralização das fontes normativas redimensionou a juridicidade para além do fundamento positivista, adequando-a expansão do Direito além da lei e dando nova configuração ao princípio da legalidade ${ }^{30}$.

Com a elevação da Constituição a parâmetro de validade formal e material de todos os atos e normas que compõem o ordenamento jurídico, a legalidade passa a corresponder, em primeiro grau, à compatibilidade dos atos oriundos da Administração Pública com a carta magna e não com a lei ou com a espécie normativa próxima ${ }^{31}$.

Observa-se, portanto, uma vinculação direta e imediata da atividade administrativa à Constituição independente da conformação legislativa, sem que resulte na exclusão como parâmetro de validade da atividade administrativa a regulamentação dada pelo legislador ordinário através da lei ou das demais espécies normativas adequadas ${ }^{32}$.

A Administração Pública permanece em grau inferior adstrita à legislação, não podendo, sob a assertiva de encontrar fundamento direto na lei fundamental e a sua alegada aplicação otimizada, desvincular a atuação administrativa para além dos domínios da lei ou eventualmente contrária as suas prescrições, ignorando a deliberação promovida no âmbito infraconstitucional ${ }^{33}$.

\footnotetext{
${ }^{29}$ A expressão Estado de Direito foi cunhada pelo liberalismo para caracterizar um Estado contido em estritos limites legais que acabou gerando um legalismo formal que deixava em segundo plano a consideração dos direitos do homem, entendendo que a supremacia da lei era garantia suficiente contra os riscos do arbítrio, em uma visão puramente formalista que não liga a expressão Estado de Direito a um conteúdo ético, político e social, sem qualquer preocupação com a legitimidade do Direito, seja pela coincidência com a vontade dos seus membros na representação, seja pela promoção dos direitos ao qual está vinculado. DALLARI, Dalmo de Abreu. p. 174-177.

${ }^{30}$ Concorrem, portanto, com a crise da concepção liberal do princípio da legalidade decorrente dentre outros, pela inflação legislativa e da ascensão da sociedade de conhecimento que amplia a complexidade das demandas sociais e demanda por celeridade na persecução do interesse público. Sobre o tema: OLIVEIRA, Rafael Carvalho Rezende. A Constitucionalidade do Direito Administrativo: O Princípio da Juridicidade, a Releitura da Legalidade Administrativa e a Legitimidade das Agências Reguladoras. Lumen Juris, 2009. Capítulo II

31 Isto representa a substituição do parâmetro de juridicidade, ou seja, da reserva vertical da lei pela reserva vertical da Constituição. Neste tocante, a introdução pela Emenda Constitucional n ${ }^{\circ} 45$ de 2004 do efeito vinculante de súmula editada pelo Supremo Tribunal Federal para a Administração Pública, demonstra que a Constituição passa a ser o fundamento primeiro de validade da atividade administrativa, e não o último, verificada após a compatibilidade com o decreto, regulamento, portaria ou demais que o ensejou. CANOTILHO, J. J. Gomes. Op. cit. p. 836.

32 Corresponderia em último grau, a concessão ao agente administrativo de uma ampliação de sua margem de discricionariedade, de modo a ensejar sob a falsa alegação de aplicação da Constituição, uma burla a obrigatoriedade da lei, com fundamento em eventual desinteresse político na realização do interesse público nela colimado, afetando, por conseguinte a segurança jurídica, advinda do caráter geral, abstrato e obrigatório da lei, ao assegurar a previsibilidade das condutas e estabilidade das relações sociais. OTERO, Paulo. Legalidade e Administração Pública: O sentido da vinculação administrativa à juridicidade. Coimbra: Almedina, 2003. p. 735.

${ }^{33} \mathrm{O}$ deslocamento da Constituição para o centro do ordenamento jurídico, não pode importar na ocupação de todo o espaço jurídico no Estado Democrático de Direito. Não é possível, que diante do Princípio Democrático, o administrador faça uma otimizada aplicação da Constituição com a ponderação direta entre os seus valores, em detrimento da norma infraconstitucional sem que importe em subtração da legitimidade conferida pelo povo ao legislador a editou, bem como violação ao sensível equilíbrio dos poderes, em razão da ingerência indevida na função tipicamente afetada a esse poder orgânico. BARROSO, Luís Roberto. Op. cit. p. 38.
}

Revista de Direito Brasileira | Florianópolis, SC | v. 22 | n. 9 | p. 4-28 |Jan./Abr. 2019 
A assunção pela Constituição do epicentro da ordem jurídica representa, portanto, a força motriz de consolidação das mudanças que tem sofrido o direito administrativo com a impregnação de seus institutos, normas e categorias administrativas pelos princípios e regras fundamentais, voltando sua atuação à concretização dos direitos fundamentais.

Por efeito, a Administração Pública em geral encontra-se sob a reserva dos direitos fundamentais, de tal sorte que, no exercício de persecução do interesse público, seja no exercício precípuo da atividade administrativa, mas também de funções residuais com a atividade legislativa ou jurisdicional, há o dever específico de tutela dos direitos do homem ${ }^{34}$.

Isso importa na execução apenas de leis adequadas formal e materialmente aos preceitos constitucionais consagradores daqueles direitos, além da interpretação de suas cláusulas gerais e conceitos jurídicos indeterminados, bem como, exercício da discricionariedade administrativa, em conformidade com os direitos fundamentais ${ }^{35}$.

Portanto, se no século XIX a lei e a fruição da liberdade individual se tornaram núcleo do Direito Público com o reconhecimento do dever estatal de não intervir na autonomia individual, no século XX, a Constituição e o reconhecimento dos direitos sociais, impõe ao Estado deveres positivos e obrigações que devem corresponder aos direitos e pretensões do administrado ${ }^{36}$.

Envolve a orientação da persecução estatal à promoção dos direitos e garantias do homem, reordenando além da relação entre a Administração Pública e o Administrado ao eixo nodal da dignidade da pessoa humana e a persecução do desenvolvimento e dos direitos fundamentais encontrando na regulação estatal e nos serviços públicos importantes instrumentos. ${ }^{37}$

A intervenção do Estado na atividade econômica não se limita a condução dos agentes econômicos a uma situação de mercado ideal com proteção da concorrência e do lucro, mas deve ter por finalidade conduzir os esforços públicos e privados ao desenvolvimento e ao bem-estar social $^{38}$.

\footnotetext{
${ }^{34}$ Note que a vinculação não abrange apenas a Administração Pública Direta, mas também, a Indireta, não apenas as pessoas jurídicas de direito público, mas aquelas de direito privado vinculadas à Administração, em todas as suas formas de atuação, seja desde os atos normativos típicos (regulamentos...) às várias medidas administrativas ou decisões de cunho jurisdicional, passando pelas próprias intervenções fáticas, nenhum atos dos entes públicos são livres dos direitos fundamentais. CANOTILHO, J. J. Gomes. Op. cit. p. 579-580.

${ }^{35}$ Decorre do dever da Administração não apenas de executar a lei em razão do Princípio da Legalidade da Separação e Independência dos Poderes, mas ao Princípio da Constitucionalidade como guardiã dos direitos fundamentais em face de leis que claramente a violam. A inexistência de um preceito expresso de rejeição da lei inconstitucional pela Administração Pública, não impede a obrigatoriedade, da mesma lançar um "olhar preventivo" relativamente a leis cuja inconstitucionalidade é evidente ou altamente provável, em razão da prevalência do princípio da vinculatividade imediata das normas garantidoras dos direitos, liberdades e garantias em relação ao princípio da legalidade. CANOTILHO, J. J. Gomes. Op. cit. p. 584-585.

${ }^{36} \mathrm{O}$ centro de gravidade da ordem jurídica transita do individual para o social, impondo ao Estado a concretização daqueles direitos fundamentais, mediante deveres positivos e obrigações de fazer, aos quais correspondem direitos e pretensões do administrado. TÁCITO, Caio. Proteção dos Direitos Fundamentais. Revista de Direito Administrativo, Rio de Janeiro, n. 194, p.1-2 out/dez 1993.

37 A centralidade assumida pelos direitos fundamentais na ordem jurídica produz uma inversão epistemológica fundamental, que torna o ser humano protagonista do direito administrativo e o Estado instrumento para a sua realização, extraindo a legitimidade de sua atuação na medida da realização destes direitos. JUSTEN FILHO, Marçal. O Direito Administrativo de Espetáculo. Fórum Administrativo Direito Público. Belo Horizonte, ano 9, n 100 p. 150 152. jun. 2009.

${ }^{38}$ Trata-se de uma intervenção promocional do Estado em países subdesenvolvidos com fins a garantir o bem-estar social e o desenvolvimento. Em um Estado Democrático de Direito o desenvolvimento econômico não pode ser deixado nas mãos do próprio mercado, diante do dever de administração e de desenvolvimento definido pela Constituição. A intervenção não gravita mais de forma a garantir um mercado concorrencial perfeito como ocorrido em momento anterior, mas em respeito à justiça social e ao princípio da dignidade da pessoa humana. MOREIRA, Egon Bockmann. O Direito Administrativo da Economia e a Atividade Interventiva do Estado Brasileiro in: OSÓRIO, Fábio Medina e SOUTO, Marcos Juruena Villela (Coord). Direito Administrativo: Estudos em Homenagem a Diogo de Figueiredo Moreira Neto. Rio de Janeiro: Lummen Juris, 2006. p 856-857 e 868.
} 
Os serviços públicos tornam-se instrumentos para a realização dos direitos fundamentais, ao garantir através do oferecimento de bens e utilidades essenciais, as prestações positivas necessárias à realização de um núcleo mínimo necessário à preservação da dignidade da pessoa humana e realização dos direitos fundamentais.

A vinculação da Administração Pública à concretização dos direitos fundamentais impõe uma atuação negativa - de abstenção ou tolerância no exercício das liberdades pelo seu titular mas também uma atividade positiva - de oferecimento de bens e serviços necessários a fruição dos bens e interesses fundamentais ${ }^{39}$.

Ocorre, inclusive, com a definição de prioridades e dispêndios, com a implementação de um sistema constitucional de financiamento, que prevê fontes de custeio para a execução de programas e ações estatais, necessárias para a implementação dos direitos fundamentais, em especial, dos direitos sociais ${ }^{40}$.

A concepção da discricionariedade administrativa de uma ampla esfera de escolha na persecução do interesse público não sujeito a controle pelos poderes públicos passa a um campo de concretização dos direitos fundamentais, mediante a ponderações proporcionais e razoáveis entre os bens e interesses constitucionais, sujeita a controle exercido pelo Poder Judiciário ${ }^{41}$.

Envolve a submissão do espaço decisório ao sistema de direitos fundamentais, que passam a orientar os juízos de valoração do administrador pelos critérios de razoabilidade e isonomia, assegurando a congruência da decisão administrativa ao interesse constitucional ou legal e o impedimento de sua tradução em arbitrariedade ${ }^{42}$.

Volta-se à regulação nos serviços públicos à garantia do oferecimento dos bens e utilidades necessárias à fruição dos bens e interesses sociais num contexto de proteção da liberdade de iniciativa, competitividade e lucro e sua orientação aos fins e objetivos colimados pela Constituição insertos na política pública setorial.

Neste sentido, o Estado propõe se concentrar apenas nas atividades típicas ou essenciais que passam a ser oferecidos através dos serviços públicos como uma forma de proteção dos direitos fundamentais dentre os quais se destaca para este estudo, a proteção da segurança pública através de políticas públicas.

\footnotetext{
${ }^{39}$ Há casos em que a Constituição consagra de forma explícita, os deveres necessários à concretização dos direitos fundamentais, como ocorre com a obrigatoriedade da prestação universal da educação fundamental e medicina de urgência, de modo que condicionar sua promoção à discricionariedade administrativa e conformação legislativa seria violação dos direitos individuais e políticos, cujo exercício pressupõe a garantia mínima do bem-estar, que envolve a realização de condições econômicas e sociais básicas. BARCELLOS, Ana Paula de. Constitucionalização das Políticas Públicas em Matéria de Direitos Fundamentais: O Controle Político-Social e o Controle Jurídico no Espaço Democrático in Revista de Direito do Estado. Ano 1. n. 3. p. 37. 2006.

${ }^{40} \mathrm{O}$ sistema de financiamento para a implementação dos direitos humanos no Brasil foi implementado pela Constituição de 1988 com a vinculação de impostos e de contribuições para custeio e ampliação dos direitos fundamentais, em especial, aqueles sociais. Não obstante, através dos contingenciamentos e desvinculação das receitas de impostos e contribuições, acarreta-se um desequilíbrio no sistema e desvio dos recursos necessários a realização daqueles direitos. SCAFF, Fernando Facury. Como a Sociedade Financia o Estado para a Implementação dos Direitos Humanos no Brasil in: SCAFF, Fernando Facury (org). Constitucionalismo, tributação e direitos humanos. Rio de Janeiro: Renovar, 2007. p. 33-34.

${ }^{41}$ Neste tocante, cabe ao Poder Judiciário a correção da discricionariedade, apurando a sua conformidade com o Direito, a racionalidade do discurso que a legitima, o atendimento ao código dos valores dominantes e a proporcionalidade na correlação lógica entre motivos, meios e fins, de forma a preservar a escolha do meio menos gravoso e proporcional aos fins a serem alcançados. CUNHA, Rubem Dário Peregrino. A juridicização da discricionariedade administrativa. Salvador: Vercia, 2005. p. 168-172.

$42 \mathrm{O}$ mérito do ato administrativo sofre um sensível estreitamento, por decorrência da incidência direta dos princípios constitucionais. A própria vinculação da Administração não apenas à Legislação, mas também a Constituição impõe diferentes graus de vinculação dos atos administrativos à juridicidade. BINENBOJM, Gustavo. A Constitucionalização do Direito Administrativo no Brasil: Direitos Humanos e Democracia como Fundamentos de Legitimidade e Elementos Estruturantes da Dogmática Administrativa in NALINI, José Renato. CARLINI, Angélica (Coord). Direitos Humanos e Formação Jurídica. Rio de Janeiro: Forense, 2010. p. 237
}

Revista de Direito Brasileira | Florianópolis, SC | v. 22 | n. 9 | p. 4-28 |Jan./Abr. 2019 


\section{DIREITO À SEGURANÇA E POLÍTICAS PÚBLICAS}

Usualmente, aponta-se que o Estado de Direito é marcado pela adoção do Princípio da Separação e Equilíbrio dos Poderes com a divisão orgânica e funcional do poder e a existência de mecanismos de checks and balances e o oferecimento de direitos fundamentais como espaço de autonomia individual e de contenção do exercício do arbítrio estatal.

Todavia, igualmente, ascende com as revoluções liberais o princípio da legalidade, não enquanto a vinculação dos particulares ao Direito produzido pelo Estado, que já ocorria no âmbito do Estado Monárquico, mas que o Estado passa a ser a única fonte produtiva normativa formal ao qual o próprio deve se submeter aos seus preceitos.

Observa-se, portanto, que tais postulados afirmam a segurança e estabilidade nas relações formadas entre o Estado e o cidadão impondo deveres ao primeiro na tutela dos direitos fundamentais e persecução do interesse público e garantias ao cidadão de uma esfera de proteção contra a atuação dos poderes públicos.

Como visto, com a passagem do Estado liberal e a concessão dos direitos subjetivos para o reconhecimento de direitos fundamentais que no Estado Democrático de Direito impõe deveres de atuação aos poderes públicos amplia-se o paradigma da segurança e estabilidade através da proteção deste valor pelas ordens contemporâneas.

Consagra expressamente a Constituição Federal de 1988 a segurança como um direito fundamental individual ${ }^{43}$ garantindo aos brasileiros natos e naturalizados e aos estrangeiros residentes no Brasil a sua respectiva inviolabilidade, que abrange a estabilidade das relações jurídicas e a previsibilidade da atuação estatal.

No que tange a estabilidade das relações jurídicas envolve a proteção do direito adquirido, do ato jurídico perfeito e da coisa julgada ${ }^{44}$ e no que tange a previsibilidade da atuação estatal, a garantia da irretroatividade da lei penal ${ }^{45}$, tributária $^{46}$ e eleitoral ${ }^{47}$, a vedação ao retrocesso e a redução dos riscos.

No que tange a redução dos riscos abrange por um lado significa a proteção do risco social através da seguridade social enquanto um conjunto integrado de ações de iniciativa dos Poderes Públicos e da sociedade, destinadas a assegurar os direitos relativos à saúde, à previdência e à assistência social. ${ }^{48}$

Por outro importa na redução do risco pessoal através das forças de segurança pública exercida para a preservação de interesses públicos - como a ordem pública - e individuais - como

\footnotetext{
${ }^{43}$ BRASIL, Constituição da República Federativa do Brasil de 05 de Outubro de 1988. Art. 5. "Todos são iguais perante a lei, sem distinção de qualquer natureza, garantindo-se aos brasileiros e aos estrangeiros residentes no País a inviolabilidade do direito à vida, à liberdade, à igualdade, à segurança e à propriedade, nos termos seguintes:"

${ }^{44}$ BRASIL, Constituição da República Federativa do Brasil de 05 de Outubro de 1988. Art. 5. "XXXVI - a lei não prejudicará o direito adquirido, o ato jurídico perfeito e a coisa julgada;"

45 BRASIL, Constituição da República Federativa do Brasil de 05 de Outubro de 1988. Art. 5. "XL - a lei penal não retroagirá, salvo para beneficiar o réu;"

46 BRASIL, Constituição da República Federativa do Brasil de 05 de Outubro de 1988. Art. 150. "Sem prejuízo de outras garantias asseguradas ao contribuinte, é vedado à União, aos Estados, ao Distrito Federal e aos Municípios: III - cobrar tributos: a) em relação a fatos geradores ocorridos antes do início da vigência da lei que os houver instituído ou aumentado;"

47 BRASIL, Constituição da República Federativa do Brasil de 05 de Outubro de 1988. Art. 16 "A lei que alterar o processo eleitoral entrará em vigor na data de sua publicação, não se aplicando à eleição que ocorra até um ano da data de sua vigência. (Redação dada pela Emenda Constitucional no 4, de 1993)”

48 BRASIL, Constituição da República Federativa do Brasil de 05 de Outubro de 1988. Art. 194. "A seguridade social compreende um conjunto integrado de ações de iniciativa dos Poderes Públicos e da sociedade, destinadas a assegurar os direitos relativos à saúde, à previdência e à assistência social."
}

Revista de Direito Brasileira | Florianópolis, SC | v. 22 | n. 9 | p.4-28 |Jan./Abr. 2019 
a proteção dos seus direitos fundamentais e, de forma estrita e geral, a incolumidade das pessoas e do seu patrimônio. ${ }^{49}$

De atribuição de todos os entes federados através de seus distintos órgãos - Polícia Federal, Polícia rodoviária federal, Polícia ferroviária federal, Polícias civis, Polícias militares e corpos de bombeiros militares e a Guarda Municipal - a concretização das atividades de prevenção, fiscalização e repressão ocorrerão através de políticas públicas.

Uma vez que a segurança pública também é um direito social ${ }^{50}$ reclama em um maior grau a realização de sua dimensão positiva, mediante adjudicações de prestações pelo Estado de natureza participativa, normativa, e em especial, material, com a criação e colocação à disposição de seus titulares os bens materiais e imateriais necessários a fruição dos bens e interesses sociais ${ }^{51}$.

$\mathrm{Na}$ nossa experiência constitucional antes restrita a Constituições garantista que tutelavam as liberdades formais como repositórios de promessas vagas ${ }^{52}$ os direitos sociais não eram concretizados e a superação ocorre com a promulgação de uma Constituição dirigente voltada à promoção social $^{53}$ e pela crescente preocupação com sua aplicabilidade direta e imediata. ${ }^{54}$

Interrompe-se, portanto, o ciclo inicial de baixa normatividade das disposições que veiculavam os direitos fundamentais, em especial, das normas que declaravam os direitos sociais, antes remetidas à esfera programática de meras linhas diretoras aos poderes públicos e, tidas como dotadas de eficácia limitada. ${ }^{55}$

Os direitos sociais enquanto veiculado por normas constitucionais gozam de exequibilidade plena, permitindo sejam os bens e interesses que tutelam exigíveis perante o Estado. ${ }^{56}$ Resta, entretanto, delimitar o conteúdo que integra as prestações passíveis de ser pleiteadas pelo cidadão em relação aos poderes públicos.

${ }^{49}$ BRASIL, Constituição da República Federativa do Brasil de 05 de Outubro de 1988. Art. 144. "A segurança pública, dever do Estado, direito e responsabilidade de todos, é exercida para a preservação da ordem pública e da incolumidade das pessoas e do patrimônio, através dos seguintes órgãos:"

${ }^{50}$ BRASIL, Constituição da República Federativa do Brasil de 05 de Outubro de 1988. Art. 6. "São direitos sociais a educação, a saúde, a alimentação, o trabalho, a moradia, o transporte, o lazer, a segurança, a previdência social, a proteção à maternidade e à infância, a assistência aos desamparados, na forma desta Constituição.”

${ }^{51}$ Isto não importa desconhecer que a concretização dos direitos sociais também depende da sua realização na dimensão negativa ou que possuem uma eficácia em relação aos particulares, impondo restrições aos direitos e liberdades ou determinando o cumprimento de dadas prestações como ocorre com as contribuições sociais. MIRANDA, Jorge. Manual de Direito Constitucional Tomo IV Direitos Fundamentais. p. 341-342.

${ }^{52}$ Não é incomum a existência formal de Constituições que invocam o que não está presente, afirmam o que não é verdade e prometem o que não será cumprido. Como, e.g., tem-se a Constituição de 1969 que garantia os direitos à integridade física e a vida, com as prisões ilegais, a tortura e o desaparecimento de pessoas na ditadura. BARROSO, Luís Roberto. O direito constitucional e a efetividade de suas normas. Limites e possibilidades da Constituição brasileira. 7. ed. Rio de Janeiro: Renovar, 2003. p. 61.

${ }^{53}$ Embora a Constituição de 1988 seja o resultado de forças políticas antagônicas que participaram da constituinte, materializando uma constante tensão entre a ideologia liberal e a perspectiva social, denota-se um grande avanço na disciplina dos direitos sociais em relação às Constituições anteriores. Para uma visão geral sobre a evolução histórica, vide: TORRES, Marcelo Nóbrega da Câmara. Direitos sociais. Brasília: Senado Federal, 1987.

${ }^{54}$ Isto ocorreu, em especial, através da doutrina brasileira da efetividade, um movimento jurídico-acadêmico que procurou elaborar as categorias dogmáticas da normatividade constitucional e superar dentre outras questões a insinceridade normativa que vigia no país. Consulte-se por todos: BARroso, Luís Roberto. O direito constitucional e a efetividade de suas normas... cit.

55 A aplicabilidade restrita das normas de natureza programática decorreria da fluidez de suas disposições e da inexistência de instrumentos jurídico-processuais capazes de garantir sua concretização.

BonAVIDES, Paulo. Curso de direito constitucional. 13. ed. São Paulo: Malheiros, 2003. p. 564-565. Compreendendo que as relações econômico-sociais são disciplinadas apenas por normas programáticas, vide: SILVA, José Afonso da. Aplicabilidade das normas constitucionais. 7. ed. São Paulo: Malheiros, 2008. Cap. IV. Em especial p. 140-142.

${ }^{56}$ As normas constitucionais tenham caráter imediato ou prospectivo como regras de conduta emanadas do Estado são dotadas de eficácia jurídica. Assim, incidem e regem as situações de vida produzindo os seus efeitos próprios, e, diante da sua inobservância espontânea deflagram mecanismos de aplicação coativa. BARROSO, Luís Roberto. Interpretação e aplicação da Constituição. 6. ed. Rio de Janeiro: saraiva, 2006. p. 248 e 274.

Revista de Direito Brasileira | Florianópolis, SC | v. 22 | n. 9 | p. 4-28 |Jan./Abr. 2019 
Neste giro, há novo deslocamento do eixo da questão, que antes gravitava em torno da aptidão para a produção dos efeitos jurídicos passa a orbitar sobre quais efeitos jurídicos podem ser produzidos, de forma a identificar as posições jurídicas que seus titulares estão investidos e, portanto, quais prestações podem ser exigidas dos poderes públicos.

Isto ocorre através da articulação pelos poderes públicos de programas, planos e diretrizes de ação governamental que coordenam a alocação da estrutura, bens e agentes disponíveis, harmonizando as atividades estatais e privadas, os variados atores e múltiplos interesses envolvidos na realização destes objetivos socialmente relevantes e politicamente determinados ${ }^{57}$.

As políticas públicas, portanto, compreende além da colocação a disposição dos recursos de forma a garantir a prestação imediata de serviços públicos pelo Estado, a atuação normativa, reguladora e de fomento que combinadas de forma eficiente conduzem os esforços da esfera pública e privada, na consecução dos fins almejados pela Constituição e a sociedade ${ }^{58}$.

De certo modo, há uma complexidade na apreensão do tema, pois a exteriorização dos programas governamentais não se apresenta com um padrão uniforme facilmente apreensível pelo sistema jurídico. Se por um lado, há uma visível proximidade com os planos ou processo, as políticas públicas antes englobam do que resumem os atos que as conformam ${ }^{59}$.

Aprioristicamente restringem-se a função política do Governo como atos decisórios que implicam na fixação de metas, diretrizes ou planos governamentais ${ }^{60}$. Todavia, conforme insertas no quadro dinâmico de ação estatal, informadas por elementos de expertise e dependentes da estrutura burocrática, também alçam a esfera da função administrativa ${ }^{61}$.

Por esta razão, envolve tanto políticas públicas quanto serviços públicos e abrange um ciclo que compreende a delimitação das metas e prioridades com o planejamento dos programas de atuação estatal, a alocação dos recursos públicos na execução destes planos e a avaliação dos impactos da ação governamental no oferecimento dos bens e serviços sociais ${ }^{62}$.

De início, o planejamento compreende o processo dialético construído a partir das demandas sociais inputs e apoios políticos e burocráticos withimputs, que resulta na escolha

\footnotetext{
57 Sob este foco, correspondem a instrumentos de ação de governo utilizados para alcançar as metas e objetivos coletivos, que redireciona o eixo da atuação estatal e da organização do governo das leis government by law para as políticas government by polices. BUCCI, Maria Paula Dallari. Direito Administrativo e Políticas Públicas. São Paulo: Saraiva, 2002. p 241-244 e 252-253.

58 Predomina em sua natureza, a intervenção cogente do Estado na realização dos bens e valores sociais, razão pelo qual, não englobam os programas realizados em associação com a sociedade civil, através de mecanismos e instrumentos institucionais ou não. BARCELLOS, Ana Paula de. Constitucionalização das Políticas Públicas em Matéria de Direitos Fundamentais: O Controle Político-Social e o Controle Jurídico no Espaço Democrático in Revista de Direito do Estado. Ano 1. n. 3. 2006. p. 18 e 22.

${ }^{59}$ As políticas públicas, portanto, distinguem-se das categorias das normas e atos jurídicos, embora compreenda esses elementos. Sob este foco, aproxima-se do conceito de atividade, enquanto conjunto organizado dessas normas e atos tendentes à realização de um objetivo determinado. BUCCI, Maria Paula Dallari. Ob. cit. 251-257.

${ }^{60}$ Trata-se de função política do Estado uma vez que corresponde à atividade dos órgãos estatais com a finalidade de conservação da sociedade política e da definição e prossecução do interesse geral mediante a escolha dentre as soluções possíveis exteriorizada em planos ou programas. CAETANO, Marcello. Manual de Ciência Política e de Direito Constitucional. Coimbra: Almedina, 2003. p. 172.

${ }^{61}$ A Administração Pública exerce um papel relevante não apenas na execução das políticas públicas, mas influencia a ação governamental auxiliando no desenho institucional do programa governamental ou subsidiando as complexas questões envolvidas na sua formulação, mediante o conhecimento e a expertise de seus agentes. Sobre o tema: MOURA, Emerson Affonso da Costa. Agências, Expertise e Profissionalismo: O Paradigma da Técnica na Administração Pública. Mimeografado. p. 12.

${ }^{62}$ As políticas públicas possuem uma configuração cíclica e não de um processo linear, uma vez que suas fases não atuam de formas isoladas e ordenadas, porém, conexas, sobrepostas e abertas a elementos externos, que torna possível surgir na avaliação a verificação de novas demandas ou na execução a necessidade simultânea de reformulação dos planos. MENY, Ives e Thoenig, Jean Claude. Lãs políticas públicas. Barcelona: Ariel, 1992.
}

Revista de Direito Brasileira | Florianópolis, SC | v. 22 | n. 9 | p.4-28 |Jan./Abr. 2019 
racional e coletiva das metas e prioridades públicas, imprimindo na gestão estatal a direção geral da política adotada pelo governo e a satisfação das necessidades sociais ${ }^{63}$.

Neste tocante, envolve a prévia identificação dos interesses em conflito oriundo dos distintos segmentos sociais, a avaliação dos fatores subjacentes - econômicos, técnicos, políticos e afins - pelo seu gabinete e a formulação das possíveis soluções que permitam a tomada de decisão pelo agente eleito das ações necessárias para o atendimento das demandas.

A execução das políticas públicas compreende o conjunto de ações que permitam a concretização dos bens e interesses socialmente almejados, através da alocação de estrutura, recursos e agentes de acordo com as metas e prioridades previamente estabelecidas nos planos e programas de direção da ação governamental visando à realização dos preceitos constitucionais.

Trata-se de processo dinâmico que demanda constante adaptação no desenho institucional das políticas públicas, inovação na implementação das respectivas ações estatais e monitoramento das estratégias empregadas, de forma a garantir a superação das questões complexas surgidas e a obtenção de resultados dotados de celeridade e eficiência. ${ }^{64}$

Por fim, a avaliação das políticas públicas envolve a correlação causal entre o programa promovido e o resultado alcançado, de forma a extrair os efeitos e impactos na promoção dos direitos sociais, identificando as ações eficientes ou promovendo o desenho de alternativas que permitam alcançar os fins socialmente desejados.

Compreende a avaliação concomitante dos processos de execução das políticas públicas ou posterior dos resultados da ação governamental, mediante o controle da efetividade dos programas propostos, da validade das estratégias utilizadas na sua implementação e o monitoramento da eficiência gerencial e operacional obtida pela ação estatal.

Baseia-se nos dados objetivos alcançados mediante a enunciação dos elementos determinantes e indicadores das ações utilizadas no planejamento e execução das políticas públicas, que permitem a criação de estudos avaliativos capazes de diagnosticar a eficiência dos processos e resultados no oferecimento dos bens e interesses socialmente almejados.

Da mesma forma como o planejamento e a execução sujeitam-se a limites que visam a preservar a legitimidade da ação estatal - aferidas na identidade dos fins e na adequação dos meios escolhidos com os objetivos traçados na Constituição e no processo eleitoral - inexiste na avaliação das políticas públicas um espaço decisório amplo para os poderes públicos ${ }^{65}$.

Neste viés, o papel da sociedade no controle das políticas públicas de segurança pública oferecida pelo Estado exerce um papel capital, na recondução da vontade pública majoritária à realização das escolhas políticas fundamentais e, portanto, a promoção dos direitos fundamentais que dependem de prestações positivas de segurança para sua concretização.

O tema será tratado a seguir.

\footnotetext{
${ }^{63}$ Sobre a experiência brasileira de planejamento e as estratégias definidas para equacionar as dificuldades surgidas, vide: COELHO NETO, Milton. A Transparência e o Controle Social como Paradigmas para a Gestão Pública no Estado Moderno in: FIGUEIREDO, Carlos Maurício e NÓBREGA, Marcos. Administração Pública: Direito Administrativo, Financeiro e Gestão Pública: Prática, Inovações e Polêmicas. São Paulo: Revista dos Tribunais, 2002. ${ }^{64}$ Em grande medida, a implementação das políticas públicas correspondem a uma formulação em processo, uma vez que não se encontra inserida em um ambiente onde há informação perfeita sobre o conteúdo dos programas de ação governamental ou problemas previamente conhecidos, mas sujeitas a superação de dificuldades como por e.g. a falta de acesso a informações, inviabilidade dos programas, limitações de tempo e de recursos, linhas múltiplas de comando, as contingências da sociedade e influências políticas no processo dentre outras. SILVA, Pedro Luiz Barros e MELO, Marcus André Barreto de. O Processo de Implementação de Políticas Públicas no Brasil: Características e Determinantes da Avaliação de Programas e Projetos. Caderno do Núcleo de Estudos de Políticas Públicas da Unicamp n. 48 . p. 8 .

${ }^{65}$ Inexistindo liberdade plena dos agentes políticos na definição dos programas de ação governamentais - diante dos fins esperados e dotações determinadas pela Constituição - e de sua execução - em razão da necessária relação de adequação dos meios empregados aos objetivos necessários - resulta que tão pouco na avaliação - com a definição dos resultados alcançados e da análise da eficácia dos projetos propostos e das medidas utilizadas - haja um espaço decisório que permitam sejam traçadas ou mantidos ações que não permitam a realização eficiente daqueles fins.
}

Revista de Direito Brasileira | Florianópolis, SC | v. 22 | n. 9 | p. 4-28 |Jan./Abr. 2019 


\section{SEGURANÇA PÚBLICA E PODER DE POLÍCIA}

Corresponde o poder de polícia, em seu sentido tradicional, a faculdade que dispõe a Administração Pública, para condicionar ou restringir o uso ou gozo de bens, atividades e direitos individuais, em razão de benefício da própria coletividade ou do próprio Estado, em nome do bemestar social, do desenvolvimento ou da segurança nacional. ${ }^{66}$

Embora usualmente associado ao exercício da função administrativa compreende o sistema total de regulação da ordem social interna, que busca preservar a ordem pública e decorre do ius imperium que possui o Estado para submeter todos aqueles que estejam sob o seu domínio territorial. ${ }^{67}$

Na tensão promovida entre autoridade da Administração Pública - com a concessão de prerrogativas e poderes - e a liberdade individual - com a sua sujeição a direitos do indivíduo - se situaria o poder de polícia, no condicionamento do último em favor do primeiro, em razão da relatividade dos direitos fundamentais. ${ }^{68}$

Assim, sistematiza-se o poder de polícia como decorrente da supremacia geral - de submissão de qualquer administrado decorrente da lei - ou, ainda, de uma relação especial de sujeição - quando assentada em relação específica ao qual se sujeita - como decorre com os servidores públicos ou concessionários. ${ }^{69}$

Uma vez que há a ampliação horizontal do complexo de atividades ao qual se incumbe o Estado-Administração não é possível delimitar o seu objeto como tentou a norma tributária ${ }^{70}$, mas tende a doutrina seu fundamento a proteção de conceitos jurídicos indeterminados as vezes passíveis de assumir cunho autoritário como a segurança nacional ou bons costumes ${ }^{71}$.

Alguns autores buscam delimitar as áreas de atuação que abrangeriam a polícia de costumes, de comunicação, sanitária, de viação, de comércio e indústria, das profissões, ambiental, de estrangeiro e edilícia, inserido em grandes campos de atuação de interesse público: a segurança, a salubridade, o decoro e a estética. ${ }^{72}$

Note, porém, que a doutrina moderna, indica que a atividade restritiva do Estado aos direitos fundamentais, deve se condicionar em uma série de princípios e regras de Direito, como a razoabilidade da conduta, a isonomia de tratamento e o respeito ao âmbito legítimo reservado as ações privadas dos homens, que não violam a ordem pública. ${ }^{73}$

Deve ser orientada pelo princípio da subsidiariedade de forma que a intervenção do Estado, no exercício do poder de polícia, deve ser apenas nos casos em que os membros da sociedade atuem de forma incapaz de garantir o respeito ou concretização dos interesses da comunidade. ${ }^{74}$

Neste caso, uma vez que o Poder de Polícia visa ao razoável equilíbrio entre os direitos individuais e os interesses da coletividade, deve condicionar os direitos individuais, mas não os tornar inservíveis, ou seja, deve regulamentar a função social já inerente ao conteúdo do direito, se alcançar o seu conteúdo mínimo, descaracterizar-se-á. ${ }^{75}$

\footnotetext{
${ }^{66}$ MEIRELLES, Hely Lopes. Direito Administrativo Brasileiro. São Paulo: Revista dos Tribunais, 2005. p. 131

${ }^{67}$ MEIRELLES, Hely Lopes. Op cit. p. 132.

${ }^{68}$ DI PIETRO, Maria Sylvia Zanella. Direito Administrativo. São Paulo: Atlas, 2014 p. 122.

${ }^{69}$ BANDEIRA DE MELLO, Celso Antônio. Curso de Direito Administrativo. São Paulo: Malheiros, 2009. p. 817.

${ }^{70}$ BRASIL, Lei n ${ }^{\circ} 5.172$ de 25 de Outubro de 1996. Art. 78. Considera-se poder de polícia atividade da administração pública que, limitando ou disciplinando direito, interesse ou liberdade, regula a prática de ato ou abstenção de fato, em razão de interesse público concernente à segurança, à higiene, à ordem, aos costumes, à disciplina da produção e do mercado, ao exercício de atividades econômicas dependentes de concessão ou autorização do Poder Público, à tranquilidade pública ou ao respeito à propriedade e aos direitos individuais ou coletivos.

${ }^{71}$ MEIRELLES, Hely Lopes. Op cit. p. 134.

${ }^{72}$ MOREIRA NETO, Diogo de Figueiredo. Op. cit. p. 445.

${ }^{73}$ CASSAGNE, Juan Carlos. Derecho Administracion. Buenos Aires: Abelado Perrot, 2002. p. 326.

${ }^{74}$ CASSAGNE, Juan Carlos. Op. cit. p. 327.

${ }^{75}$ ARAGÃO, Alexandre de. Curso de Direito Administrativo. Rio de Janeiro, Forense: 2013. p. 180.
}

Revista de Direito Brasileira | Florianópolis, SC | v. 22 | n. 9 | p.4-28 |Jan./Abr. 2019 
Liga-se, portanto, a noção de núcleo essencial do direito fundamental, de maneira que, a título de realização do bem ou interesse coletivo, não pode ser capaz de alcançar a essencialidade do direito subjetivo, sob pena da restrição importar anulação, o que configura desrespeito a ordem jurídico-constitucional e abuso pelo agente público ${ }^{76}$.

Assim, nos sistemas constitucionais onde estão consagrados os direitos fundamentais da pessoa humana, o princípio vigente é favor libertatis, de forma que a restrição por interesse público é excepcional, sendo vedado o seu uso indiscriminado das medidas quando outros podem ser utilizados. $^{77}$

Neste viés, submete-se a restrição do poder de polícia, à observância do princípio da proporcionalidade exigindo que a medida seja adequada - capaz de atingir o bem comum almejado - necessária - inexistir outra menos gravosa para tal fim - e proporcional - relação necessária entre a limitação ao direito individual e o bem almejado.

Tal juízo de proporcionalidade e razoabilidade deve obedecer um processo objetivo e racional, de valoração justificada e adequada dos antecedentes necessários, a proporção adequada a finalidade legal da medida, para a prática do ato de polícia com a restrição da liberdade individual $^{78}$.

Note-se que, o poder de polícia pode ser administrativo - através da aplicação da lei ao caso concreto, mediante medidas repreensivas e preventivas - e o poder de polícia legislativo - que decorre de normas gerais e abstratas dirigidas a restringir de forma abstrata dado comportamento humano. $^{79}$

$\mathrm{Na}$ ordem jurídico-brasileiro, a restrição e condicionamento das liberdades e direitos fundamentais, devem ser tidas como uma exceção às suas cor respectivas afirmações e garantias constitucionais, daí a razão pela qual somente possa ser exercido sob estrita reserva legal, ou seja, por via do poder de polícia normativo, função reservada ao legislador. ${ }^{80}$

Neste viés, as políticas públicas de segurança pública devem ser realizadas de forma a conter a violência e buscar a paz, porém, sem que importe em restrição desmedida aos direitos fundamentais erigindo o controle social como importa proteção de conformação dos referidos planos de ação à proteção do cidadão.

O tema será tratado a seguir.

\section{AS POLÍTICAS PÚBLICAS DE SEGURANÇA E O CONTROLE SOCIAL}

A gestão pública é marcada por uma estrutura deficitária, desperdício de recursos, desvios de verbas e ineficiência dos agentes estatais, que resultam na precariedade dos serviços prestados na promoção dos direitos sociais e tornam necessária a definição de controle de políticas públicas ${ }^{81}$.

O controle político dos programas de ação governamental realizado pelo Poder Legislativo no seu âmbito administrativo-financeiro, embora dotado de instrumentos jurídicos eficientes para

\footnotetext{
${ }^{76}$ DIEZ, Manuel Maria. Manual de Derecho Administrativo. Tomo 2. DIEZ, Manuel Maria. Manual de Derecho Administrativo. Tomo 2. Buenos Aires: Plus Ultra, 1997. p. 187.

${ }^{77}$ CASSAGNE, Juan Carlos. Op. cit. p. 343.

${ }^{78}$ DIEZ, Manuel Maria. Op. cit. p. 203-204.

${ }^{79}$ DI PIETRO, Maria Sylvia Zanella. Op. cit. p. 126.

${ }^{80}$ MOREIRA NETO, Diogo de Figueiredo. Op. cit. p. 439.

${ }^{81}$ Isto resta exemplificado na pesquisa que aponta que os recursos destinados à área social dos três níveis federativos em todas as regiões do país em 1995 eram três vezes maiores que o volume de recursos necessários para a erradicação da pobreza no Brasil. BARROS, Ricardo Paes, HENRIQUES, Ricardo e MENDONÇA, Rosane. A Estabilidade Inaceitável: desigualdade e pobreza no Brasil. Rio de Janeiro: Ipea, 2001. p. 723.
} 
fiscalização ${ }^{82}$ têm se demonstrado incapaz de atribuir responsabilidade aos agentes públicos e garantir a correção na persecução dos interesses sociais ${ }^{83}$.

Em um contexto, onde se verifica uma redução do processo democrático às deliberações majoritárias, a gestão e controle das políticas públicas no âmbito da esfera política são marcadas por corrupção, ineficiência e clientelismo, que geram o atendimento precário dos interesses públicos e o deslocamento da atribuição da responsabilidade aos agentes para o controle judicial ${ }^{84}$.

Neste viés, torna-se necessário analisar as políticas públicas de segurança pública realizadas pelo Estado de forma identificar as suas falhas e verificar a importância do controle social como forma de garantir mecanismos adequados de conformar a vontade política à realização dos interesses tutelados pela Constituição.

Compreende o controle social, um conjunto de instrumentos empregados pela sociedade, capaz de induzir a conformação das pessoas às normas de comportamento que a caracteriza, ordenando a sua atuação no ambiente social e estabelecendo as condições necessárias para que sejam alcançados os fins e objetivos almejados pelo grupo social ${ }^{85}$.

Exterioriza-se em duas esferas de normatização distinta, conforme opere em um ambiente externo, mediante a utilização de mecanismos de constrição pela própria sociedade por instituições formais ou não - penas e obrigações judiciais, reprovação e admoestação social entre outros - ou interno conforme sujeita a mecanismos de coerção psíquica realizada pela pessoa ${ }^{86}$.

Os instrumentos e extensão do controle social variam conforme as demandas advindas das questões políticas, econômicas, morais e afins extraídas da realidade subjacente, que importam em maior ou menor grau de inserção na esfera de autonomia das pessoas, gerando consequentes restrições na sua atuação externa independente sejam entes naturais ou fictícios.

Sob tal égide, sendo o Estado à expressão formal da organização político-jurídico do grupo social em dado território com objetivo de garantir sua soberania e os fins e objetivos propostos, ao qual é atribuído o exercício do poder político para a persecução destes interesses prospectivos, sua atuação igualmente se sujeita a um controle exercido pela sociedade ${ }^{87}$.

\footnotetext{
${ }^{82}$ Compreende dentre outros a sustação de atos e contratos do Executivo (artigo 49 inciso $\mathrm{V}$ e $71 \S 1^{\circ}$ ), julgamentos de suas contas (artigo 49 inciso IX, artigo 51 inciso II e artigo 57) autorização ou aprovação do Congresso para atos concretos do Executivo (artigo 49 inciso I, XII, XIII, XVI e XVII), instalação de Comissão Parlamentar de Inquérito (artigo $58 \S 3^{\circ}$ ), a suspensão e destituição do Presidente e ministros por crimes de responsabilidade (artigo 85 e 86 todos da Constituição).

${ }^{83}$ Observa-se ainda uma deficiente fiscalização das políticas públicas no controle parlamentar, na atribuição de responsividade aos agentes ou correção de seus atos. Como exemplo, a constante aprovação das contas públicas federais realizadas fora do prazo e desconsideradas as recomendações dos relatórios técnicos ou as manobras políticas que ocorrem nas Comissões Parlamentares de Inquérito que não resultam na atribuição de responsabilidade. OLIVEIRA, Farlei Martins Riccio de. Controle de Legitimidade das Políticas Públicas: Limites e Possibilidades. Revista de Direito Administrativo, 247 jan./abr. de 2008 p. 72-73.

${ }^{84}$ Por efeito, há o desperdício no emprego dos recursos públicos nas políticas públicas, sem que se alcance bons resultados na promoção dos direitos sociais e das condições da sociedade participar de forma adequada no processo democrático. Diante da constante troca de favores políticos que não permite uma apuração das responsabilidades, transfere-se para o Poder Judiciário o controle da ação estatal, que representa mais um paliativo do que uma medida capaz de sanar essas dificuldades. BARCELLOS, Ana Paula de. Ob. cit. p. 27.

${ }^{85}$ Trata-se o controle social, portanto, da capacidade de auto-regulação de um grupo social baseada na reiteração dos comportamentos necessários ou úteis para alcançar seus objetivos globais, obtidos mediante o consenso ou coerção dos indivíduos. BOBBIO, Noberto, MATTEUCCI, Nicola e PASQUINO, Gianfranco. Dicionário de Política. Brasília: Editora UNB, 1986. p. 283-284.

${ }^{86}$ Embora possa repousar a constrição no predomínio da força - mediante a utilização de instrumentos de coerção, como as penas institucionalizadas pela ordem jurídica - repousa a legitimidade do controle social, enquanto compromisso valorativo voltado à redução da coerção e alcance das metas sociais, no consenso - através do reconhecimento da necessidade da prática da conduta para a realização dos fins sociais, pela utilização de debates, compromissos e outros meios. BERGALLI, Roberto. Controle Social: Suas Origens Conceituais e Usos Instrumentais in: Revista Brasileira de Ciências Instrumentais. n 3. Jul/set 1993. p. 33-34.

${ }^{87}$ Revestindo-se o poder político de atributo que o Estado concentra e exerce sob a sociedade organizada apenas como um instrumento a serviço dos seus fins supera-se a concepção da posição de supremacia dos poderes públicos nas
} Revista de Direito Brasileira | Florianópolis, SC | v. 22 | n. 9 | p.4-28 |Jan./Abr. 2019 
Mediante o controle social do poder se garante a cooperação entre os atores estatais e nãoestatais na coordenação dos múltiplos e complexos interesses, auxiliando na formação de um espaço público que baseado na negociação e consenso atribui um maior grau de legitimidade, transparência, racionalidade e eficiência à persecução dos fins sociais ${ }^{88}$.

Importa na construção entre a sociedade e os poderes públicos de um vínculo de compromisso e responsabilidade acerca das decisões estatais, que contribui no aprimoramento dos mecanismos de exercício da cidadania, além de coibir os desvios de legalidade, garantindo previsibilidade e segurança nas relações jurídico-públicas.

Em um modelo estatal vigente, marcado pela coexistência de duas forças antagônicas - a ideologia liberal - exteriorizada na liberdade da iniciativa privada e a auto regulação da economia - e a perspectiva social - traduzida na intervenção do Estado na busca do desenvolvimento social, o controle social corresponde à importante instrumento também na proteção e promoção dos direitos sociais ${ }^{89}$.

Ademais, em razão da evidente ineficiência e déficit de legitimidade dos programas governamentais na adjudicação das prestações referentes aos bens e interesses sociais, o controle social torna-se o campo adequado para permitir a correção da atuação estatal - contribuindo na busca pela efetividade das políticas públicas - e na atribuição de responsabilidade dos agentes políticos ${ }^{90}$.

De certo, não se ignora as dificuldades na efetivação da participação dos cidadãos na gestão pública. Observa-se atualmente, dificuldades no controle social em razão do persistente desinteresse e apatia da sociedade pelo debate político ${ }^{91}$, bem como, da atuação burocrática, autoritária e hierarquizada dos poderes estatais na gestão político-administrativa dos interesses públicos $^{92}$.

Neste tocante, erige-se a necessidade de uma otimização da publicidade dos atos estatais, de modo a viabilizar com a transparência na gestão pública o debate político ${ }^{93}$, a utilização de

relações com os indivíduos, para compreender que sendo a sociedade titular do poder político é a atividade estatal que se encontra subordinada aos seus interesses do grupo social e, portanto, sujeita ao seu controle.

${ }^{88}$ Demonstra-se através da participação dos destinatários da atuação estatal no processo de deliberação pública e de fiscalização (legitimidade); nos argumentos e informações obtidos com a dialética promovida pelos atores envolvidos (racionalidade), do conhecimento das razões utilizadas como fundamentos da decisão estatal (transparência), e da escolha por consenso das medidas mais eficazes para alcançar os resultados almejados (eficiência).

${ }^{89}$ Decorre da consagração pela Constituição da dignidade da pessoa humana e da livre iniciativa como valores fundamentais da ordem jurídica (artigo $1^{\mathrm{o}}$ inciso III e IV). Neste tocante, embora se verifique avanços na ordem econômico-financeira com crescentes índices de exportação e receitas públicas, tão pouco se ignora o atraso na promoção dos direitos sociais, perceptível no triste retrato da miséria e pobreza nos grandes bolsões dos centros urbanos.

${ }^{90}$ A eficiência do planejamento e implementação das políticas públicas encontra-se, em grande medida, associada à participação dos indivíduos no controle realizado pela sociedade do desempenho da atividade administrativa e da qualidade dos serviços públicos prestados.

NASSUNO, Marianne. O Controle Social nas Organizações Sociais no Brasil in: Pereira, L.C.B. e GRAU, N.C. (Org.) O Público Não-Estatal na Reforma do Estado. Rio de Janeiro: FGV, 1999. p. 344.

91 Trata-se de fenômeno com fundamentos diversos, que variam desde a impossibilidade de participação devido às condições de pobreza extrema e baixo nível de educação de grande parte da população, da dificuldade de acesso às informações sobre as questões políticas e a falta de tempo para debater e manifestar sobre tais assuntos, até mesmo a descrença de que sua participação seja capaz de influenciar na ação pública. BARCELLOS, Ana Paula de. Papéis do Direito Constitucional no Fomento do Controle Social Democrático: Algumas Propostas Sobre o Tema da Informação in RDE ano 3. N. 12. Out/dez 2008. p. 82-84.

$92 \mathrm{O}$ comportamento autoritário e endógeno dos poderes instituídos, que consideram existir uma autossuficiência gerencial e política em relação à sociedade, dificulta o exercício do controle social, criando uma relação artificial e de distanciamento entre os poderes constituídos e a comunidade que deveriam servir. LEAL, Rogério. O Controle social dos serviços públicos no Brasil como condição de sua possibilidade. Revista de Direito Administrativo e Constitucional, Belo Horizonte, n. 13, jul/set 2003. p. 158.

${ }^{93}$ Apenas com o conhecimento das informações referentes à elaboração e execução dos planos governamentais, bem como, da estrutura e modo de atuação dos órgãos político-administrativos envolvidos é capaz de ser realizado o

Revista de Direito Brasileira | Florianópolis, SC | v. 22 | n. 9 | p. 4-28 |Jan./Abr. 2019 
mecanismos de fortalecimento sociocultural da cidadania e fomento da participação popular ${ }^{94}$, bem como, o aperfeiçoamento da gestão estatal ${ }^{95}$ e dos instrumentos jurídicos de controle social ${ }^{96}$.

Isto não importa, todavia, em desconsiderar a centralidade assumida pelo controle social na fiscalização dos poderes públicos, em especial, no que se concerne às limitações das arenas políticas e jurídicas em se tratando de controle da legitimidade e eficiência dos programas governamentais e de atribuição de responsabilidade política aos agentes estatais.

Exterioriza apenas a necessidade de aprimoramento do controle social, mediante a garantia das condições necessárias e promoção de meios capazes de ampliar a participação dos atores sociais na deliberação política estatal e a negociação com os poderes públicos nas decisões públicas, na construção de uma gestão pública comunicativa ${ }^{97}$.

No âmbito da segurança pública torna-se essencial o controle pela sociedade tendo em vista a construção de políticas públicas de forma repressiva pelo Ente Estatal e não garantidora dos direitos fundamentais como resposta aos conflitos de desigualdade, da explosão de violência e a crescente criminalidade que ocorrem nos espaços urbanos.

Tal construção da ação governamental, todavia, em torno da proteção da ordem pública não se insere em um espaço de construção de cidadania ativa pode ser verificado nas políticas públicas de segurança no âmbito federal nas últimas quadras históricas que será objeto de análise ao longo deste trabalho.

\section{CONCLUSÃO}

Sob a égide um Estado Constitucional e Democrático de Direito, a atuação dos poderes públicos passa a ser condicionada por escolhas políticas fundamentais realizadas pela carta de organização estatal, bem como, pelas decisões majoritárias tomadas no âmbito da deliberação política pública.

Nesta tensão entre constitucionalismo e democracia, há de se afirmar que embora todas as decisões políticas não possam estar submetidas à vontade constitucional perene, que por outro lado, há limites no que tange a decisões essenciais tomadas pela comunidade, que devem ser tida pelos poderes constituídos no exercício do princípio democrático e republicano.

Sob tal viés, a consagração de um catálogo de direitos fundamentais impõe aos poderes públicos não apenas o dever de proteção, mas de promoção, dos bens jurídicos tutelados por esses

controle social permitindo que os cidadãos possam influir na ação estatal. MILESKI, Helio Saul. Controle Social: Um Aliado do Controle Oficial. Interesse Público n. 36 mai./abr. 2006. p. 87.

${ }^{94}$ Trata-se de medidas que busquem um exercício pleno da cidadania ativa necessária para o controle social, através de investimentos na educação que permitam a conscientização política e social dos cidadãos, na ampliação dos espaços públicos de atuação participativa e o desenvolvimento de uma cultura política baseada na ética. SILVA, Francisco Carlos da Cruz. Controle Social: Reformando a Administração Para a Sociedade in: Perspectivas para o Controle Social e a Transparência da Administração Pública. Brasília: Tribunal de Contas da União, Instituto Serzedello Corrêa, 2002. p. $51-55$

${ }^{95}$ Pressupõe o controle social a superação do perfil burocrático Estatal, que permita mediante a descentralização e profissionalização da gestão administrativo-financeira, um efetivo espaço de participação da sociedade na gestão dos interesses públicos e controle da atuação estatal. COELHO NETO, Milton. Op. cit. p. 316-321.

96 Torna-se necessária a construção de instrumentos jurídicos de controle social que permitam a vinculação da atuação estatal às decisões promovidas no âmbito da deliberação pública - definidas no processo eletivo e na participação na gestão estatal - e a atribuição de responsabilidade pelos desvios de eficiência e legitimidade promovidos pelos agentes públicos na persecução dos interesses públicos.

${ }^{97}$ Neste sentido, as políticas públicas coordenadas por agentes com a participação democrática e em respeito às redes sociais, garantem os arranjos institucionais adequados e a deliberação popular nas decisões, viabilizam o desenvolvimento da sociedade. Sobre o tema, vide: SCHMIDT, João Pedro. Capital social e políticas públicas in: LEAL, Rogerio Gesta e ARAUJO, Luiz Ernane Boresso de. Direitos sociais e políticas públicas: Desafios contemporâneos. Tomo II. Santa Cruz do Sul: Edunisc, 2003. Em especial p. 446-456. 
direitos públicos subjetivos, o que impõe, ao Estado-Legislador a adoção das medidas normativas cabíveis e ao Estado-Administração as políticas necessárias à sua fruição.

Deste modo, na concretização dos direitos fundamentais há o dever estatal de segurança que impõe o conjunto de políticas públicas normativas e administrativas, que permitam a proteção e promoção dos direitos do cidadão, através de ações que garantam a incolumidade das pessoas e do seu patrimônio.

Todavia, isto não importa que nas políticas públicas de segurança pública o exercício do poder de polícia com a restrição das liberdades e garantias será realizada de forma desmedida, mas que devem ser observadas as garantias constitucionais, bem como, o princípio da proporcionalidade.

Inegável que isto envolve a necessidade de controle social das políticas públicas de segurança pública evitando que o Estado no exercício do poder de polícia judiciário com a restrição da propriedade e liberdade dos cidadãos possa atuar de forma desmedida e a título de ação contra a violência atente contra os próprios direitos fundamentais.

Por efeito, com o controle social amplia-se mais que a participação popular na ação administrativa, mas garante-se maior grau de legitimidade e racionalidade na decisão pública permitindo que as políticas públicas de segurança reflitam as escolhas sociais, bem como, possua grau maior de adesão e consenso pela dialética promovida.

\section{REFERÊNCIAS}

ALEXY, Robert. Teoria dos Direitos Fundamentais. Malheiros: São Paulo, 2008.

ANDRADE, José Carlos Vieira de. Direitos Fundamentais na Constituição de 1976. Coimbra: Almedina, 2001.

ARAGÃO, Alexandre Santos. Direito dos Serviços Públicos. 2 ed. Rio de Janeiro: Forense, 2005.

ASSONI FILHO, Sergio. Transparência Fiscal e Democracia. Porto Alegre: Nuria Fabris Editora, 2009.

ÁVILA, Humberto. Repensando o "Princípio da Supremacia do Interesse Público Sobre o Particular" in SARMENTO, Daniel (Org). Interesses Públicos vs. Interesses Privados:

Desconstruindo o Princípio de Supremacia do Interesse Público. Rio de Janeiro: Lumen Juris, 2005.

BAPTISTA, Patrícia. Transformações do Direito Administrativo. Rio de Janeiro: Renovar, 2003.

BARCELlOS, Ana Paula de. Constitucionalização das Políticas Públicas em Matéria de Direitos Fundamentais: O Controle Político-Social e o Controle Jurídico no Espaço Democrático in Revista de Direito do Estado. Ano 1. n. 3. 2006.

BARCELlOS, Ana Paula de. Papéis do Direito Constitucional no Fomento do Controle Social Democrático: Algumas Propostas Sobre o Tema da Informação in RDE ano 3. N. 12. Out/dez 2008.

BARROS, Ricardo Paes, HENRIQUES, Ricardo e MENDONÇA, Rosane. A Estabilidade Inaceitável: desigualdade e pobreza no Brasil. Rio de Janeiro: Ipea, 2001. 
BARROSO, Luís Roberto. Neoconstitucionalismo e constitucionalização do direito: O triunfo tardio do direito constitucional no Brasil. In: SOUZA NETO, Cláudio Pereira de; SARMENTO, Daniel (orgs.). A constitucionalização do direito: fundamentos teóricos e aplicações específicas. Rio de Janeiro: Lumen Juris, 2007.

BARROSO, Luís Roberto. O direito constitucional e a efetividade de suas normas. Limites e possibilidades da Constituição brasileira. 7. ed. Rio de Janeiro: Renovar, 2003.

BARROSO, Luís Roberto. Interpretação e Aplicação da Constituição. 6 ed. Rio de Janeiro: Saraiva, 2006.

BEREIJO, Álvaro Rodriguez. El Presupuesto del Estado. Madrid: Editorial Tecnos, 1970.

BERGALLI, Roberto. Controle Social: Suas Origens Conceituais e Usos Instrumentais in: Revista Brasileira de Ciências Instrumentais. n 3. Jul/set 1993.

BINENBOJM, Gustavo. Uma Teoria do Direito Administrativo: Direitos Fundamentais, Democracia e Constitucionalização. Rio de Janeiro: Renovar, 2006.

BINENBOJM, Gustavo. A Constitucionalização do Direito Administrativo no Brasil: Direitos Humanos e Democracia como Fundamentos de Legitimidade e Elementos Estruturantes da Dogmática Administrativa in NALINI, José Renato. CARLINI, Angélica (Coord). Direitos Humanos e Formação Jurídica. Rio de Janeiro: Forense, 2010.

BOBBIO, Noberto. O Futuro da Democracia: Uma Defesa das Regras do Jogo. 5 ed. Rio de Janeiro: Paz e Terra, 1986.

BOBBIO, Noberto. MATTEUCCI, Nicola e PASQUINO, Gianfranco. Dicionário de Política. Brasília: Editora UNB, 1986.

BONAVIDES, Paulo. Curso de direito constitucional. 13. ed. São Paulo: Malheiros, 2003.

BONAVIDES, Paulo. Do Estado Liberal ao Estado Social. 8 ed. São Paulo: Malheiros, 2007.

BORGES, Alice Gonzales. Supremacia do Interesse Público: Desconstrução ou Reconstrução? Revista Diálogo Jurídico, Salvador, n. 15, 2007.

BUCCI, Maria Paula Dallari. Direito Administrativo e Políticas Públicas. São Paulo: Saraiva, 2002.

CAETANO, Marcello. Manual de Ciência Política e de Direito Constitucional. Coimbra: Almedina, 2003.

CASTRO, Carlos Roberto Siqueira. A Constituição Aberta e os Direitos Fundamentais: ensaios sobre o constitucionalismo pós-moderno e comunitário. Rio de Janeiro: Forense, 2010.

CANOTILHO, José Joaquim Gomes. Direito Constitucional. 6 ed. Rev e atual. Coimbra: Almedina, 1993. 
CANOTILHO, José Joaquim Gomes. Direito Constitucional e Teoria da Constituição. 7. Ed. Coimbra: Livraria Almedina, 2003.

CARBONELL, Miguel. Nuevos Tiempos para el Constitucionalismo in: CARBONELL, Miguel (Org). Neoconstitucionalismo(s). 1 ed. Madrid: Editorial Trotta, 2003.

CARVELLI, Urbano. SCHOOL, Sandra. Evolução Histórica dos Direitos Fundamentais: Da Antiguidade até as Primeiras Importantes Declarações Nacionais de Direito. Revista de Informação Legislativa, Brasilia, a. 48 n. 191

COELHO, Rosa Júlia Plá. Mecanismos de Proteção dos Direitos Fundamentais. 1 ed. Brasília: Ordem dos Advogados do Brasil, 2005.

COELHO NETO, Milton. A Transparência e o Controle Social como Paradigmas para a Gestão Pública no Estado Moderno in: FIGUEIREDO, Carlos Maurício e NÓBREGA, Marcos. Administração Pública: Direito Administrativo, Financeiro e Gestão Pública: Prática, Inovações e Polêmicas. São Paulo: Revista dos Tribunais, 2002.

CUNHA, André Luiz Nogueira da. Direitos Políticos. 1 ed. São Paulo: Juarez de Oliveira, 2004.

CUNHA, Rubem Dário Peregrino. A juridicização da discricionariedade administrativa. Salvador: Vercia, 2005.

DAL BOSCO, Maria Goretti. Discricionariedade em políticas públicas. Curitiba: Juruá, 2007.

DALLARI, Dalmo de Abreu. Elementos de teoria geral do estado. 19. ed. São Paulo: Saraiva, 1995.

DALLARI, Dalmo de Abreu. Estado de Direito e Direitos Fundamentais in: AMLEIDA FILHO, Agassiz de. CRUZ, Danielle da Rocha (Coord). Estado de direito e direitos fundamentais: homenagem ao jurista Mário Moacyr Porto. Rio de Janeiro: Forense, 2005.

DELGADO, Maurício Godinho. Democracia e Justiça. São Paulo: LRT, 1993.

DERBLI, Felipe. Proibição de Retrocesso Social: Uma Proposta de Sistematização à Luz da Constituição de 1988 in: BARROSO, Luís Roberto (Org). A Reconstrução Democrática do Direito Público no Brasil. Renovar: Rio de Janeiro, 2007.

DIMOULIS, Dimitri. MARTINS, Leonardo. Teoria Geral dos Direitos Fundamentais. São Paulo: Editora Revista dos Tribunais, 2008.

DI PIETRO, Maria Sylvia Zanella de. Direito Administrativo. 22 ed. São Paulo: Atlas, 2009.

DI PIETRO, Maria Sylvia Zanella de. Da Discricionariedade Administrativa. São Paulo: Atlas, 1990.

DI PIETRO, Maria Sylvia Zanella de. Participação Popular na Administração Pública. Revista de Direito Administrativo n. 191 jan/mar 2003. 
FALLA, Fernando Garrido. Las Transformaciones Del Regime Administrativo. Madri: Instituto de Estudios Politicos, 1962.

FERRAJOLI, Luigi. Derechos e Garantias: La ley del mais débil. 1 ed. Madrid: Trotta, 1999.

GONZÁLEZ, Jorge Agudo. Evolución y negación del derecho subjetivo. In Revista Digital de Derecho Administrativo, Universidad Externado Colombia n. 05, jan./jun. 2011.

HELLER, Hermann. Teoría del estado. 1. ed. México: Fondo de Cultura Econômica, 1942.

HESSE, Konrad. A força normativa da Constituição. Porto Alegre: Sergio Antonio Fabris Ed., 1991.

JELLINEK, Georg. Teoría general del Estado. Trad. Fernando de Los Rios. Bueno Aires: Editorial Albatros, 1973;

JUSTEN FILHO, Marçal. O Direito Administrativo de Espetáculo. Fórum Administrativo Direito Público. Belo Horizonte, ano 9, n 100 jun. 2009.

LASSALLE, Ferdinand. Que é uma Constituição. São Paulo: Edições e Publicações Brasil, 1933.

LEAL, Rogério. O Controle social dos serviços públicos no Brasil como condição de sua possibilidade. Revista de Direito Administrativo e Constitucional, Belo Horizonte, n. 13, jul/set 2003.

LUÑO, Antonio Enrique Perez. Los Derechos Fundamentales. Madrid: Tecnos, 2004.

MARTINS JUNIOR, Wallace Paiva. Transparência Administrativa, Publicidade, Motivação e Participação Popular. São Paulo: Saraiva, 2004.

MEIRELLES, Hely Lopes. Direito Administrativo Brasileiro. 30 ed atual por Eurico de Andrade Azevedo, Délcio Balestero Aleixo, José Emmanuel Burle Filho. Malheiros: São Paulo, 2005.

MELLO, Celso Antônio Bandeira de. Curso de Direito Administrativo. 21 ed rev e atual. Malheiros: São Paulo, 2006.

MELLO, Celso Antônio Bandeira de. São Paulo: Malheiros, 1992.

MENDES, Gilmar. Direitos Fundamentais e Controle de Constitucionalidade: Estudos de Direito Constitucional. 3 ed. Rev e ampla. São Paulo: Saraiva, 2004.

MENDONÇA, Eduardo. Alguns Pressupostos Para Um Orçamento Público Conforme a Constituição in: BARROSO, Luís Roberto. A Reconstrução Democrática Do Direito Público no Brasil. Rio de Janeiro: Renovar, 2007.

MENDONÇA, Eduardo. Da Faculdade de Gastar ao Dever de Agir: O Esvaziamento Contramajoritário das Políticas Públicas. Revista de Direito do Estado. n. 9 jan/mar 2000.

MENY, Ives e Thoenig, Jean Claude. Lãs políticas públicas. Barcelona: Ariel, 1992. 
MILESKI, Helio Saul. Controle Social: Um Aliado do Controle Oficial. Interesse Público n. 36 mai/abr 2006.

MIRANDA, Jorge. Teoria do estado e da constituição. Trad. Edição Portuguesa. Rio de Janeiro: Forense, 2002.

MIRANDA, Jorge. Os Direitos Fundamentais: Sua Dimensão Individual e Social. Cadernos de Direito Constitucional e Ciência Política, nº 1, out/dez 1992.

MOREIRA, Egon Bockmann. O Direito Administrativo da Economia e a Atividade Interventiva do Estado Brasileiro in: OSÓRIO, Fábio Medina e SOUTO, Marcos Juruena Villela (Coord). Direito Administrativo: Estudos em Homenagem a Diogo de Figueiredo Moreira Neto. Rio de Janeiro: Lummen Juris, 2006.

MOREIRA NETO, Diogo de Figueiredo. Teoria do poder: sistema de direito político: estudo juspolítico do poder. São Paulo: Revista dos Tribunais, v. I, 1992.

MOREIRA NETO, Diogo de Figueiredo. Mutações do Direito Administrativo. 2 ed. atual e ampla Rio de Janeiro: Renovar, 2001.

MOREIRA NETO, Diogo de Figueiredo. Direito da Participação Política. Rio de Janeiro: Renovar, 1992.

MOREIRA NETO, Diogo de Figueiredo. Legitimidade e Discricionariedade. 3 ed. Rio de Janeiro: Forense, 1998.

MOREIRA NETO, Diogo de Figueiredo. Quatro Paradigmas do Direito Administrativo PósModerno. Belo Horizonte: Fórum, 2008.

MULLER, Mathias Haroldo. A Democracia Participativa na Legislação Brasileira. Revista Interesse Público n. 38 jul/ago 2006

NASSUNO, Marianne. O Controle Social nas Organizações Sociais no Brasil in: Pereira, L.C.B. e GRAU, N.C. (Org.) O Público Não-Estatal na Reforma do Estado. Rio de Janeiro: FGV, 1999.

NEGREIROS, Teresa. Dicotomia público-privado frente ao problema de colisão de princípios in TORRES, Ricardo Lobo (Org.). Teoria dos Direitos Fundamentais. Rio de Janeiro: Renovar, 2009.

OLIVEIRA, Farlei Martins Riccio de. Controle de Legitimidade das Políticas Públicas: Limites e Possibilidades. Revista de Direito Administrativo, 247 jan/abr de 2008.

OTERO, Paulo. Legalidade e Administração Pública: O sentido da vinculação administrativa à juridicidade. Coimbra: Almedina, 2003.

PALU, Oswaldo Luiz. Controle dos Atos de Governo pela Jurisdição. São Paulo: Revista dos Tribunais, 2004.

REALE, Miguel. Teoria do Direito e do Estado. 4d. ed. Rev. São Paulo: Saraiva, 1984. 
SANTOS, Boaventura de Souza. Orçamento Participativo em Porto Alegre: Para Uma Democracia Redistributiva in: SANTOS, Boaventura de Souza (Org.). Democratizar a democracia: os caminhos da Democracia participativa. Rio de Janeiro: Civilização Brasileira, 2002.

SARMENTO, Daniel. O neoconstitucionalismo no Brasil: Riscos e possibilidades. In: SARMENTO, Daniel (org.). Filosofia e teoria constitucional contemporânea. Rio de Janeiro: Lumen Juris, 2009.

SARMENTO, Daniel. Direitos Fundamentais e Relações Privadas. Rio de Janeiro: Lumen Juris, 2004.

SARMENTO, Daniel. Interesses públicos vs. Interesses privados na perspectiva da teoria e da filosofia constitucional. in SARMENTO, Daniel (Org). Interesses Públicos vs. Interesses Privados: Desconstruindo o Princípio de Supremacia do Interesse Público. Rio de Janeiro: Lumen Juris, 2005.

SARLET, Ingo Wolfgang. A Eficácia dos Direitos Fundamentais. 10 ed. rev atual e ampla. Porto Alegre: Livraria do Advogado, 2009.

SCAFF, Fernando Facury. Como a Sociedade Financia o Estado para a Implementação dos Direitos Humanos no Brasil in: SCAFF, Fernando Facury (org). Constitucionalismo, tributação e direitos humanos. Rio de Janeiro: Renovar, 2007.

SCHIER, Paulo Ricardo. Ensaio sobre a Supremacia do Interesse Público sobre o Privado e o Regime Jurídico dos Direitos Fundamentais. Revista de Estudos Criminais, Ano 4, n. 13, 2004.

SCHMITT, Carl. Teoría de la Constitucíon. 1 ed. Alianza Editorial S.A.: Madrid, 1982.

SCHMIDT, João Pedro. Capital social e políticas públicas in: LEAL, Rogerio Gesta e ARAUJO, Luiz Ernane Boresso de. Direitos sociais e políticas públicas: Desafios contemporâneos. Tomo II. Santa Cruz do Sul: Edunisc, 2003.

SERRA, José. Orçamento no Brasil: as Raízes da Crise. São Paulo: Atual, 1994.

SILVA, Francisco Carlos da Cruz. Controle Social: Reformando a Administração Para a Sociedade in: Perspectivas para o Controle Social e a Transparência da Administração Pública. Brasília: Tribunal de Contas da União, Instituto Serzedello Corrêa, 2002.

SILVA, José Afonso da. Aplicabilidade das normas constitucionais. 7. ed. São Paulo: Malheiros, 2008.

SILVA, Pedro Luiz Barros e MELO, Marcus André Barreto de. O Processo de Implementação de Políticas Públicas no Brasil: Características e Determinantes da Avaliação de Programas e Projetos. Caderno do Núcleo de Estudos de Políticas Públicas da Unicamp n. 48.

SILVA, Vasco Manuel Pascoal Pereira da. Em busca do Acto Administrativo Permitido. Coimbra: Almedina, 1998. 
SOUZA NETO, Cláudio Pereira de. Teoria Constitucional e Democracia Deliberativa. Renovar: Rio de Janeiro, 2006.

STUMM, Raquel Denize. Princípio da Proporcionalidade no Direito Constitucional Brasileiro. Porto Alegre: Livraria do Advogado, 1995.

SUNDFELD, Carlos Ari. A Administração Pública na Era do Direito Global. Revista Diálogo Jurídico, Salvador, ano I, vol 1, nº 2, maio/2001.

TÁCITO, Caio. Proteção dos Direitos Fundamentais. Revista de Direito Administrativo, Rio de Janeiro, n. 194, out/dez 1993.

TAVARES, Marco Aurélio Romagnloi. Ativismo judicial e políticas públicas: direitos fundamentais. Porto Alegre: Sergio Antonio Fabris, 2011.

TORRES, Marcelo Nóbrega da Câmara. Direitos Sociais. 1 ed. Brasília: Senado Federal, 1987.

VALLE, Vanice Lirio do. Direito fundamental a boa administração, Políticas Públicas Eficientes e a Prevenção do Desgoverno. Revista Interesse Público, n. 48 mar/abr de 2007. 